\title{
G.C. Oeder's conflict with Linnaeus and the implementation of taxonomic and nomenclatural ideas in the monumental Flora Danica project (1761-1883)
}

\author{
I. Friis \\ Natural History Museum of Denmark, \\ University of Copenhagen, \\ Universitetsparken 15, DK-2100 \\ Copenhagen $\varnothing$, Denmark. \\ ibf@snm.ku.dk
}

\begin{abstract}
Hitherto unpublished parts of the history of the Icones ... Florae Danicae (1761-1883), one of the largest illustrated botanical works published, are analysed; it covered the entire flora of the double monarchy of Denmark-Norway, Schleswig and Holstein and the North Atlantic dependencies. A study of the little noticed taxonomic and nomenclatural principles behind the Icones is presented. G.C. Oeder, founder of the project, approved the ideas of Buffon and Haller and rejected Linnaean binary nomenclature because of its lack of stability of genera. In the Icones ..., Oeder cited all names used for each plant in chronological order, with the binary Linnaean name last, to which principle Linnaeus reacted. By the end of the 18th century, Linnaean nomenclature had become standard, apart from in Flora Danica and a very few other botanical works. Applying Linnaean nomenclature elsewhere, O.F. Müller, editor 1775-1782, and M. Vahl, editor 1787-1799, followed Oeder's norm in the Icones. J.W. Hornemann, editor 1810-1840, followed Oeder in his first fascicles, but began experimenting with changes towards Linnaean nomenclature from 1810. After 1840, subsequent editors consistently applied Linnaean principles for accepted names and synonyms.
\end{abstract}

Keywords. Accepted names, genera, natural classification, species, synonymy

\section{Introduction}

In his excellent monograph on how the Linnaean reforms gained general acceptance among botanists, Stafleu (1971: 260) specifically stated that he left out a discussion of C.G. Oeder's views on the Linnaean revolution: "Many personalities have been left out of this account or could be mentioned only incidentally. ... It would also have been interesting to trace the influence of Linnaeus for instance in Denmark, with O.F. Müller ... and G.C. Oeder and their Flora Danica ...". This paper attempts to fill this gap.

Numerous publications have dealt with the illustrations of the Icones ... Florae Danicae (Oeder et al., 1761-1883; hereafter 'the Icones'), the main product of the Flora Danica project, or with the broad historical outline of the project. In his history of botany in Denmark, Christensen (1924-1926a, 1924-1926b, in Danish) presented such an outline of the history of the Flora Danica project, based on the published works and archival material at the Danish National Archives and at the University 
of Copenhagen. Buchheim (1979) produced a bibliographic study of the Icones. The Librarian of the Botanical Library of Copenhagen, P. Wagner, has undertaken further archival studies and published papers on many aspects of the history of the Flora Danica project and the Royal Botanical Institute established in Copenhagen to support the project (Wagner 1990a, 1990b, 1994, in Danish and English). Knudsen (2014, 2016, in Danish and English) has summarised the general history of the Flora Danica project and published reproductions of 253 plates from the Icones.

Among these authors, only Christensen (1924-1926a) has dealt with Oeder's scientific ideas and his conflict with Linnaeus. However, Christensen did not refer to the letters exchanged between Oeder and Linnaeus or notice the subsequent delayed introduction of Linnaean nomenclature in the Icones. Friis (1996) analysed the new taxa of vascular plants published in the Icones and concluded that the slow publication of the work itself meant that most new species discovered in connection with the Flora Danica project were published via faster channels before they appeared in the Icones. Recently, Lack (2018) has published a review of the introduction of the Linnaean ideas about nomenclature in the countries around the Baltic Sea. For Denmark, Lack mentioned Oeder's idea of citing synonymies in chronological order and other controversies in Denmark over this subject. The purpose of the present paper is to compare Oeder's ideas with the views of contemporary botanists, present translations of the letters exchanged between Oeder and Linnaeus regarding the nomenclature in the Icones, and to see to what degree Oeder's successors as editors of the Icones followed Oeder's views.

\section{The editors and products of the Flora Danica project (paper and china)}

G.C. Oeder (1728-1791), born in Ansbach, then a principality of the Holy Roman Empire, now in Bavaria, Germany, had studied medicine and science with Albrecht von Haller (1708-1777) in Göttingen and settled as a medical doctor in the town of Schleswig, then under the Danish crown (Christensen, 1924-1926a: 69-74). The Danish government wanted to further scientific research, not least on the economically important science of botany, and J.H.E. von Bernstorff, a leading member of the government, invited Oeder to Copenhagen in 1752 to an unspecified position with a yearly allowance of 400 Danish Rix-Dollars. Once in Copenhagen, Oeder prepared to defend a thesis on physiology at the University, a required step in order to allow Oeder to fill a new university-chair, even if the government sponsored it. However, ex auditorio the students Carl Jensenius and Christian Friis Rottbøll attacked Oeder's thesis so vigorously that the University rejected it. Oeder could therefore not be employed at the University, but the government decided to proceed on its own and encouraged Oeder to submit directly to the government proposals for a project on the study of plants in the possessions of the King of Denmark-Norway.

Oeder then drafted a proposal for the Flora Danica project and an associated Royal Institution established independently of the University. The proposal, with a pro memorium dated 6th December, 1753, is preserved in the Danish National Archives. 
I have not seen it, but it was reviewed by Christensen (1924-1926b: 48). After Royal approval, Oeder went on a study tour in 1754-1755 to botanical institutions in the Netherlands, England, France and Germany. His stay with the French scientists in Paris particularly seems to have influenced his thinking. Returning from this journey, he was appointed Royal Professor of Botany, and in 1756-1761 continued his work with a long journey through Norway to collect material for the Flora Danica project.

In 1759, a Royal commission had finished drafting instructions for Oeder's work with the project and the Royal Institute. However, none of the members of the committee was a scientifically trained botanist, and the committee therefore requested the young botanist G. T. Holm (1726-1759) to comment on Oeder's plans. Holm had studied under Linnaeus in Uppsala in 1750-1751 and again in 1754-1757. Just before he left Uppsala, he had defended a thesis on the Danish flora, based on previous literature and a few original observations by Holm himself (Linnaeus, 1757, 1760: 30-49), and he wrote three long manuscripts with critical discussion of Oeder's project. I have not been able to trace the final manuscript of the Flora Danica committee's instructions, which were never printed in extenso. According to Christensen (1924-1926a: 93-95), the instructions left out directions relating to Holm's academic criticism. Instead, the instructions dealt mostly with the practical aspects of the project and the production of a practical manual of uses and harm of all the plants in the flora.

The first printed product of the project was the programmes published in Danish (Oeder, 1761a), Latin and French (Oeder, 1761b) and German (Oeder, 1761c). A synthesis in English of these rather similar texts is reproduced in Appendix 1 and presents Oeder's views on taxonomy and nomenclature. According to Oeder's plans of 1753, the Flora Danica project should produce a whole sequence of works, all with the words Flora Danica in their titles: (1) An introduction to the science of botany; (2) A systematic enumeration of all plants, in a pocket format and without descriptions, in fact a check-list of the flora; (3) A descriptive work, comparable to a modern flora manual; (4) A complete set of illustrations of all plants known from the flora area; and (5) A practical manual containing descriptions of the beneficial and harmful properties of all the plants in the flora. The flora area covered not only the present Kingdom of Denmark, including the Faeroe Islands and Greenland, but also Duchies of Schleswig and Holstein (then ruled by the King of Denmark, after 1920 the Danish-German border divides the former duchy of Schleswig), the whole of Norway, and Iceland. Oeder was to travel extensively in these territories. To produce the illustrations, Oeder employed Michael Rössler (1705-1777), a highly qualified engraver from Nuremberg, and his son, Martin Rössler (1727-1782), who would draw the plants in the field with Oeder.

The first published output after the programme was No. 1, the introduction to botany, which appeared as two sizeable volumes in three parallel editions with titles and texts in Latin (Oeder, 1764a, 1766a), in German (Oeder, 1764b, 1766b) and in Danish (Oeder, 1764c, 1766c). Throughout these books, Oeder maintained that species existed as persistent units in nature, albeit variable, and could be observed with empirical methods, while genera were artificial creations of botanists. The two volumes run to a total of 402 pages and 14 plates, and are arranged in thirteen numbered divisions and 
242 sections, the latter indicated with $\S$ signs and Arab numerals. Apart from those, there were very few headings in the book, making it difficult to find the treatment of particular subjects. The first four divisions contained a general introduction to the study of botany, an introduction to the morphology of plants, and highly generalised descriptions of floras and climates of different parts of the world and habitats where plants can grow. The fifth, sixth and seventh divisions attempted to give a morphological definition of how to recognise species, but stressed that even within species, there might be considerable morphological variation and that species might hybridise. In these sections, Oeder distinguished between consistent characters, shared by an entire class, family or genus, and varying characters, which characterise individual species, and he attempted to give general rules for the use of characters in classification. In $\S 121$, Oeder concluded that all understanding of kinship, all systematic uniformity and all good scientific method should follow a basic rule, which was contrary to the Linnaean sexual system. Species of plants should not be brought together in higher categories because of similarity in a single character, when they were different in many other characters, and they should not be separated because they were different in a single character when they were similar in many others.

Oeder also distinguished between artificial classifications, based on similarity and differences of a priori selected characters, and natural classifications based on what he called the true relationship of plants, but our imperfect knowledge restricted progress with the study of the latter, and different botanists had reached very different conclusions. According to Oeder, this has serious practical consequences on the level of the genus, as most nomenclatural systems combined the name of the genus with one or more words indicating the species, and that the full species names therefore changed with different generic concepts.

In the eighth division, which mainly dealt with nomenclature, Oeder began with a discussion of the advantages and disadvantages of descriptions versus illustrations. Illustrations were easier to understand than descriptions, but they could never represent all observations that botanists have made on individual plants of a species and could not easily represent variation. Yet, a good illustration was always to be preferred for an imperfect description. He continued with discussions of various uses of names, particularly the differences between plant names for everyday use in a restricted geographical area and names which have to be applied everywhere where people may meet the plant. In $\S 144$, which is the last in the first volume, he stated that the so-called trivial names for species, the Linnaean nomina trivialia, did not merit to be called names, but were in fact short descriptive references to the plants. Oeder did not see the advantage of how Linnaeus in Article 257 of Philosophia botanica (Linnaeus, 1751) distinguished between nomina specifica legitima, where a descriptive phrase would change with the discovery of new species, and nomina trivialia, where the epithet consists of one word chosen from all kind of sources and was not to be changed.

In the second volume, Oeder $(1766 \mathrm{a}, 1766 \mathrm{~b}, 1766 \mathrm{c})$ reviewed various systems used for the classification of plants, beginning with his own original natural classification, with the classes $(\mathrm{A}-\mathrm{H})$ and the families $(\mathrm{AA}-\mathrm{HI})$, and genera numbered 1-418 (but only temperate genera are included). In the natural classification, Oeder's 
classes were, for example: (B) Plants with apical germination, Monocotyledones; (C) Plants with flowers in catkins, Amentiferae; (G) Plants with sympetalous flowers, Monopetalae; (H) Plants with choripetalous flowers, Polypetalae.

Oeder circumscribed some of his families as later botanists have done, for example: (BG) Orchid-like plants, Orchideae [all genera in present-day Orchidaceae]; (EA) Plants with flowers together in heads, Compositae [all genera in present-day Asteraceae]; (EC) Plants with flowers in umbels, Umbelliferae [all genera in presentday Apiaceae]; (GA) Plants with helicoid inflorescence and four naked seeds, Asperifoliae [all genera in present-day Boraginaceae.]; (GE) Plants with anthers in no fixed position, Bicornes [genera in present-day Ericaceae, but also Tamarix (only one species, which occurs in Norway and is now in Myricaria, Tamaricaceae); Oeder's characterisation of this family, "anthers in no fixed position" is not appropriate, the anthers in this group are fixed to the filaments in one point only, and the resemblance of Myricaria to the remaining genera in the group is only superficial]; (HF) Plants which have flowers with four petals looking like a cross, Tetrapetalae cruciatae [all genera in present-day Brassicaceae]; (HI) Plants with pea-like flowers, Papilionaceae [genera in present-day Fabaceae, but also Polygala, Polygalaceae]. Other of Oeder's groups had no resemblance with the circumscription used by later botanists; for example Oeder's group (C) Plants with capsules and berries, Capsuliferae \& Baccatae; with the genera (131) Mercurialis, (132) Euphorbia, (133) Hippophae, (134) Viscum, (135) Thesium, (136) Daphne, and (137) Asarum .

After the detailed presentation of his own system, Oeder outlined in $\S 147-$ 164 the ordines naturales of Linnaeus, Adanson (1727-1806), Adriaan van Royen (1704-1779) and Albrecht von Haller (1708-1777), the classes of Joseph Pitton de Tournefort (1656-1708), Herman Boerhaave (1668-1738), the sexual system of Linnaeus, the groups of Christian Gottlieb Ludwig (1709-1773) and of Johann Gottlieb Gleditsch (1714-1786), Andrea Cesalpino (1519-1603), Robert Morison (1620-1683), John Ray (1627-1705), Paul Hermann (1646-1695), Christoph Knaut (1638-1694), August Qvirin Rivinius (1652-1723), and Christian Knaut (16561716), the system of Linnaeus according to the perianth, and finally the system of Evert Jacob von Wachendorff (1703-1758). In the tenth division, Oeder elaborated his own natural system with a series of classifications of the genera in northern Europe according to characters from the perianth $(\S 166$ and $\S 167)$, from the androecium and gynoecium ( $(168)$, from the fruits $(\S 169)$, from a combination of characters from both perianth and the androecium and gynoecium $(\S 170)$, and finally a system based on characters from the leaves $(\S 171)$. The eleventh division $(\S 172-207)$ is a very detailed discussion of Oeder's own classes and families. Finally, the twelfth division is an outline of the history of botany ( $\$ 208-225)$, followed by a comparisons of the various floras of Europe and a discussion of history of the exploration of that continent with digressions about the herbals and horticulture ( $\$ 226-239)$, and the thirteenth division is a review of previous major botanical works ( $\$ 240-242)$. Oeder's ideas of a natural system appeared more than 20 years before the one by Antoine-Laurent de Jussieu (1748-1836), who, however, in Genera Plantarum (Jussieu, 1789) covered all then known plants, not only Northern European, as Oeder's system did. 
Publication No. 2 of the Flora Danica project, the systematic enumeration of all plants thought to occur in the territories of the King of Denmark, was planned to be published early, but that did not happen. Instead, Oeder published an alphabetically arranged dictionary of plant names in French, English, German, Swedish, Danish and Latin (Oeder, 1769a, 1769b, 1769c), again with title pages and introductions in Latin, German and Danish. For the scientific names in Latin, Oeder used the Linnaean binary nomenclature for species.

Again, publication No. 3 of the project, the descriptive floristic work, did not appear as originally planned. Instead, a work rather similar to the intention behind No. 2 was published in Latin and German (Oeder, 1770a, 1770b), but Oeder only managed to cover the cryptogams before dramatic Danish revolutions involving Johann Friederich Struensee (1737-1772) in the years 1770-1772, which first set back Oeder's involvement with the Flora Danica project, and later forced him to leave it completely. In June 1770, the botanical garden and library of the Royal Botanic Institution in Copenhagen, which had been established to form the foundation of the Flora Danica project, were handed over to the professor of botany, Christian Friis Rottbøll, at the University of Copenhagen, the very person who in 1752 had successfully resisted Oeder's employment as professor at the university. Therefore, again, in 1770, Oeder did not get employment at the University, but was able to continue the Flora Danica project on a significantly reduced scale with direct Royal support. After the coup d'etat against Struensee in 1772, Oeder had to leave the Flora Danica project completely and was sent to Oldenburg as a sheriff (Christensen, 1924-1926a). Shortly after, the reign of the Danish King Christian VII ceased in Oldenburg, which then had no further direct contact with Denmark-Norway, and consequently Oeder had no further involvement with regard to continuation of part No. 3, or any other part of the Flora Danica project.

The most ambitious part of Oeder's project, No. 4, the Icones, continued to be published with illustrations and synonymies for each illustrated plant over a span of 122 years (Oeder et al., 1761-1883; see Table 1). The major changes in the Latin titles are listed here in Table 1, but similar changes happened with the German and Danish title pages. The completed Icones is an impressive work of 17 volumes in folio, with a total of 3240 coloured plates issued in 51 fascicles edited (and the short texts mostly written) by seven different editors. The work realised Oeder's ideas about the importance of illustrations, and his texts were restricted to a nomenclatural block with selected synonyms and an indication of the locality of the illustrated plant.

After the coup d'état in Denmark in 1772, and Oeder's subsequent departure, the work with the Flora Danica project came to a temporary standstill. However, there was a sufficient number of interested and high-ranking people to secure the continuation of the most prestigious part of the project, the Icones. In 1774, Otto Friderich Müller (1730-1784) was appointed editor to continue the work with that part of the project. Hornemann (1837) wrote about Müller's appointment: "When Oeder's work with the editing of Flora Danica came to an end, [Otto Friderich Müller] an excellent student of natural history was appointed as successor. Müller had established a name as a zoologist; he was experienced with microscopic studies and had close 
Table 1. The fascicles and volumes of the Icones. All fascicles contained 60 plates; each three fascicles formed a volume with a title page. The work appeared in different editions with Danish, German and Latin text (here with the Latin title pages for each sequence of volumes with similar title pages). The repeated words can be translated like this: "Illustrations of the plants growing wild in the Kingdom[s] of ..., in the Duchies of ... and in the Counties of ...: to illustrate the work covering these plants, which under the title of Flora Danica have been published on Royal order." The changes in the geographical indications on the title pages reflect that the Danish Crown lost Oldenburg, Delmenhorst and Norway, but in exchange it gained Lauenburg. The title pages never mentioned the Faroe Islands, Iceland and Greenland, but plants from these areas formed an important part of the work. Plants from the small Danish colonies in India, West Africa and the Caribbean were never part of the project. In 1853-1874, a supplementary volume presented plants from Norway and Sweden not illustrated before 1814. Editors of the volumes are indicated as on the title pages; editors of fascicle are indicated as by Christensen (1924-1926b) and Buccheim (1979).

\begin{tabular}{|l|l|l|l|l|l|}
\hline Volume & $\begin{array}{l}\text { Year of completion } \\
\text { and editor(s) } \\
\text { indicated on title } \\
\text { page of volume }\end{array}$ & Fascicle & $\begin{array}{l}\text { Year of } \\
\text { publication } \\
\text { of fascicle }\end{array}$ & $\begin{array}{l}\text { Plate } \\
\text { numbers }\end{array}$ & $\begin{array}{l}\text { Editor(s) of } \\
\text { fascicles }\end{array}$ \\
\hline
\end{tabular}

Icones Plantarum sponte nascentium in Regnis Daniae et Norvegiae, in Ducatibus Slesvici et Holsatiae, et in comitatibus Oldenburgi et Delmenhorstiae: Ad illustrandum opus de iisdem Plantis, Regio jussu exarandum, Florae Danicae nomine inscriptum.

\begin{tabular}{|c|c|c|c|c|c|}
\hline \multirow{3}{*}{1} & \multirow{3}{*}{$\begin{array}{l}1766 \\
\text { G. C. Oeder }\end{array}$} & 1 & 1761 & $1-60$ & \multirow{11}{*}{ G.C. Oeder } \\
\hline & & 2 & 1763 & $61-120$ & \\
\hline & & 3 & 1764 & $121-180$ & \\
\hline \multirow{3}{*}{2} & \multirow{3}{*}{$\begin{array}{l}1767 \\
\text { G. C. Oeder }\end{array}$} & 4 & 1765 & $181-240$ & \\
\hline & & 5 & 1766 & $241-300$ & \\
\hline & & 6 & 1767 & $301-360$ & \\
\hline \multirow{3}{*}{3} & \multirow{3}{*}{$\begin{array}{l}1770 \\
\text { G. C. Oeder }\end{array}$} & 7 & 1768 & $361-420$ & \\
\hline & & 8 & 1769 & $421-480$ & \\
\hline & & 9 & 1770 & $481-540$ & \\
\hline \multicolumn{5}{|c|}{$\begin{array}{l}\text { Icones Plantarum sponte nascentium in Regnis Daniae et Norvegiae, in Ducatibus } \\
\text { Slesvici, Holsatiae et Oldenburgi: Ad illustrandum opus de iisdem Plantis, Regio } \\
\text { jussu exarandum, Florae Danicae nomine inscriptum. }\end{array}$} & \\
\hline \multirow{3}{*}{4} & \multirow{3}{*}{$\begin{array}{l}1777 \\
\text { O. F. Müller }\end{array}$} & 10 & 1771 & $541-600$ & \\
\hline & & 11 & 1775 & $601-660$ & \multirow{5}{*}{ O.F. Müller } \\
\hline & & 12 & 1777 & $661-720$ & \\
\hline \multirow{3}{*}{5} & \multirow{3}{*}{$\begin{array}{l}1782 \\
\text { O. F. Müller }\end{array}$} & 13 & 1778 & $721-780$ & \\
\hline & & 14 & 1780 & 781-840 & \\
\hline & & 15 & 1782 & $841-900$ & \\
\hline & & 16 & 1787 & $901-960$ & \multirow{6}{*}{ M. Vahl } \\
\hline 6 & $\begin{array}{l}1792 \\
M \quad \text { Vahl }\end{array}$ & 17 & 1790 & $961-1020$ & \\
\hline & & 18 & 1792 & $1021-1080$ & \\
\hline \multirow{3}{*}{7} & \multirow{3}{*}{$\begin{array}{l}1799 \\
\text { M. Vahl }\end{array}$} & 19 & 1794 & $1081-1140$ & \\
\hline & & 20 & 1797 & $1141-1200$ & \\
\hline & & 21 & 1799 & $1201-1260$ & \\
\hline
\end{tabular}


Table 1. Continuation.

\begin{tabular}{|c|c|c|c|c|c|}
\hline Volume & $\begin{array}{l}\text { Year of completion } \\
\text { and editor(s) } \\
\text { indicated on title } \\
\text { page of volume }\end{array}$ & Fascicle & $\begin{array}{l}\text { Year of } \\
\text { publication } \\
\text { of fascicle }\end{array}$ & $\begin{array}{l}\text { Plate } \\
\text { numbers }\end{array}$ & $\begin{array}{l}\text { Editor(s) of } \\
\text { fascicles }\end{array}$ \\
\hline \multicolumn{6}{|c|}{$\begin{array}{l}\text { Icones Plantarum sponte nascentium in Regnis Daniae et Norvegiae, in Ducatibus Slesvici et Holsatiae } \\
\text { Ad illustrandum opus de iisdem Plantis, Regio jussu exarandum, Florae Danicae nomine inscriptum. }\end{array}$} \\
\hline \multirow{3}{*}{8} & \multirow{3}{*}{1810 J.W. Hornemann } & 22 & 1806 & $1261-1320$ & \multirow{3}{*}{$\begin{array}{l}\text { J.W. } \\
\text { Hornemann }\end{array}$} \\
\hline & & 23 & 1808 & $1321-1380$ & \\
\hline & & 24 & 1810 & $1381-1440$ & \\
\hline \multicolumn{6}{|c|}{$\begin{array}{l}\text { Icones Plantarum sponte nascentium in Regnis Daniae, et in Ducatibus Slesvici, Holsatiae et } \\
\text { Lauenburgiae: Ad illustrandum opus de iisdem Plantis, Regio jussu exarandum, Florae Danicae } \\
\text { nomine inscriptum. }\end{array}$} \\
\hline \multirow{3}{*}{9} & \multirow{3}{*}{$\begin{array}{l}1818 \\
\text { J.W. Hornemann }\end{array}$} & 25 & 1813 & $1441-1500$ & \multirow{15}{*}{$\begin{array}{l}\text { J.W. } \\
\text { Hornemann }\end{array}$} \\
\hline & & 26 & 1816 & $1501-1560$ & \\
\hline & & 27 & 1818 & $1561-1620$ & \\
\hline \multirow{3}{*}{10} & \multirow{3}{*}{$\begin{array}{l}1823 \\
\text { J.W. Hornemann }\end{array}$} & 28 & 1819 & $1621-1680$ & \\
\hline & & 29 & 1821 & $1681-1740$ & \\
\hline & & 30 & 1823 & $1741-1800$ & \\
\hline \multirow{3}{*}{11} & \multirow{3}{*}{$\begin{array}{l}1828 \\
\text { J.W. Hornemann }\end{array}$} & 31 & 1825 & $1801-1860$ & \\
\hline & & 32 & 1827 & $1861-1920$ & \\
\hline & & 33 & 1829 & $1921-1980$ & \\
\hline \multirow{3}{*}{12} & \multirow{3}{*}{$\begin{array}{l}1834 \\
\text { J.W. Hornemann }\end{array}$} & 34 & 1830 & $1981-2040$ & \\
\hline & & 35 & 1832 & $2041-2100$ & \\
\hline & & 36 & 1834 & $2101-2160$ & \\
\hline \multirow{3}{*}{13} & \multirow{3}{*}{$\begin{array}{l}1840 \\
\text { J.W. Hornemann }\end{array}$} & 37 & 1836 & $2161-2220$ & \\
\hline & & 38 & 1839 & $2221-2280$ & \\
\hline & & 39 & 1840 & $2281-2340$ & \\
\hline \multirow{3}{*}{14} & \multirow{3}{*}{$\begin{array}{l}1849 \\
\text { F.M. Liebmann }\end{array}$} & 40 & 1843 & $2341-2400$ & $\begin{array}{l}\text { J.F. Schouw } \\
\text { and J. Vahl }\end{array}$ \\
\hline & & 41 & 1845 & $2401-2460$ & \multirow{3}{*}{$\begin{array}{l}\text { F.M. } \\
\text { Liebmann }\end{array}$} \\
\hline & & 42 & 1849 & $2461-2529$ & \\
\hline \multirow{3}{*}{15} & \multirow{3}{*}{$\begin{array}{l}1861 \\
\text { F.M. Liebmann \& J. } \\
\text { Lange }\end{array}$} & 43 & 1852 & $2521-2580$ & \\
\hline & & 44 & 1858 & $2781-2640$ & $\begin{array}{l}\text { J. Steenstrup } \\
\text { and J. Lange }\end{array}$ \\
\hline & & 45 & 1861 & $2641-2700$ & \multirow{7}{*}{ J. Lange } \\
\hline \multirow{3}{*}{16} & \multirow{3}{*}{$\begin{array}{l}1871 \\
\text { J. Lange }\end{array}$} & 46 & 1867 & $2701-2760$ & \\
\hline & & 47 & 1869 & $2761-2820$ & \\
\hline & & 48 & 1871 & $2821-2880$ & \\
\hline \multirow{3}{*}{17} & \multirow{3}{*}{$\begin{array}{l}1883 \\
\text { J. Lange }\end{array}$} & 49 & 1877 & $2881-2940$ & \\
\hline & & 50 & 1880 & 2941-3000 & \\
\hline & & 51 & 1883 & $3001-3060$ & \\
\hline
\end{tabular}


Table 1. Continuation.

\begin{tabular}{|l|l|l|l|l|l|}
\hline Volume & $\begin{array}{l}\text { Year of completion } \\
\text { and editor(s) } \\
\text { indicated on title } \\
\text { page of volume }\end{array}$ & Fascicle & $\begin{array}{l}\text { Year of } \\
\text { publication } \\
\text { of fascicle }\end{array}$ & $\begin{array}{l}\text { Plate } \\
\text { numbers }\end{array}$ & $\begin{array}{l}\text { Editor(s) of } \\
\text { fascicles }\end{array}$ \\
\hline $\begin{array}{l}\text { Icones Plantarum sponte nascentium in Regnis Sueciae et Norvegiae. Supplementum Operis Florae } \\
\text { Danicae nomine inscripti. }\end{array}$ \\
\hline \multirow{2}{*}{$\begin{array}{l}\text { Supplement } \\
\text { volume }\end{array}$} & $\begin{array}{l}1874 \\
\text { F.M. Liebmann \& J. } \\
\text { Lange }\end{array}$ & 1 & 1853 & $1-60$ & $\begin{array}{l}\text { F.M. } \\
\text { Liebmann }\end{array}$ \\
\cline { 2 - 6 } & 2 & 1865 & $61-120$ & J. Lange \\
\cline { 2 - 6 } & 3 & 1874 & $121-180$ & \\
\hline
\end{tabular}

connection with Professor [Christen Friis] Rottbøll, who was the University professor with responsibility for botany. [Rottbøll], however, had too many other academic duties to take over the editing of this work, and Müller's connection with Rotbøll and [Johan Theodor] Holmskiold (the author of the well-known work on fungi "Beata ruris otia") was undoubtedly the reason for this appointment, rather than Müller's name as a botanist. Müller's Flora Fridrichsdalina, although better known in Europe than many other Danish works on botany, could hardly be a qualification for this post" (my translation from Danish). In order to further his knowledge of medicine, chemistry and botany, Rotbøll had studied a year with Linnaeus in Uppsala and travelled in 17571761 in Germany, the Netherlands and France. He became professor designatus in medicine at the University of Copenhagen with responsibility for botany, and since his year in Uppsala, he had been a strong supporter of the Linnaean methods. Holmskiold was also trained in medicine and botany, and was a close friend of Rottbøll whom he had accompanied on the journey in 1757-1761. Holmskiold became director of the postal services of Denmark-Norway and from 1772 director of the Royal Copenhagen Porcelain Factory.

After Müller's death in 1784, the next editor, Martin Vahl (1749-1804), was appointed in 1785. He had studied under Linnaeus for five years, and had travelled in most of Western Europe and North Africa. The subsequent editor, Jens Wilken Hornemann (1770-1841) was a student of Martin Vahl's, and had also travelled widely in Europe. He had qualified for the post by publishing a flora manual of Denmark (Hornemann, 1796). In November 1814, after the Treaty of Kiel, Norway left the Danish-Norwegian double monarchy in exchange for a personal union with Sweden, and Norwegian plants were therefore omitted from the Icones after 1814. However, Hornemann included an increasing number of plants from the North Atlantic dependencies, particularly new species from Greenland, based on collections made by Hornemann's pupils, including Morten Wormskiold (1783-1845) and Jens Vahl (1796-1854; son of Martin Vahl). In his later years, Hornemann was not well. The young botanist Salomon Drejer (1813-1842) collected plants for Flora Danica on his behalf, and after Hornemann's death, Drejer took over the publication of the Icones, but died shortly after without finishing the publication of a fascicle. He was therefore 
only responsible for the initial editing of fascicle 40, which his colleagues Joachim Frederik Schouw (1789-1852) and Jens Vahl edited.

F. M. Liebmann (1813-1856), who was Hornemann's son-in-law, became Hornemann's successor. However, many of the plates in the three fascicles 41, 42 and 43 formally published by Liebmann, really presented the initial work of Drejer and Jens Vahl. After Liebmann's death, the zoologist Japetus Steenstrup (1813-1897) and Johan Lange (1818-1898) jointly edited fascicle 44, after which Johan Lange took over the completion of the work. In 1874, Lange had concluded a supplement of Norwegian and Swedish plants in three fascicles, and, as the final addition to the whole work, a revised nomenclatural index, Nomenclator "Florce Danicae" (Lange, 1887).

The coloured plates, many of high quality, had already made the Icones a wellknown work during Oeder's time as editor (Wagner, 1990a, 1990b, 1994). However, the reputation of the work was considerably enhanced by a dinner service with the name of Flora Danica, produced in the 1780s to 1790s for the King of Denmark on the Royal Copenhagen Porcelain Factory. This commission was undoubtedly due to the botanical interests of Johan Theodor Holmskiold, trained as a botanist and later director of the Royal Danish Porcelain Factory, and his Royal protector, the Dowager Queen Juliane Marie (Bencard, 2000). Of this dinner service, 1530 original pieces are preserved at Christansborg and Rosenborg Castles. The decoration on each piece is based on a specific plate in the Icones, referred to by its plate number underneath. A new set of the Flora Danica dinner service, but only with 765 pieces, was produced in Copenhagen as a gift to the daughter of King Christian IX, Princess Alexandra. The occasion for this was her marriage in 1863 to Edward, Prince of Wales, the later King Edward VII (Nottelmann, 1990, 1994, both in Danish; Bencard, 2000, in Danish). This set is now at Windsor, with pieces on display in the China Museum (Anonymous, 2019).

\section{Oeder's ideas of taxonomy and nomenclature, and his conflict with Linnaeus}

Already in the debate in 1757 between Holm and Oeder, it is possible to perceive how some of Oeder's ideas for the Flora Danica project conflicted with the views of Linnaeus. Although Holm's arguments against Oeder are relevant, it will be too complicated to describe their discussion in detail, and I have not seen the unpublished manuscripts where these views are expressed. Christensen (1924-1926a: 128-129), who had studied these manuscripts, has summarised the debate like this: as in Oeder (1761a, 1761b, 1761c, 1764a, 1764b, 1764c, 1766a, 1766b, 1766c), Oeder's manuscript Abhandlung von der Kräuter-Kenntniss argued that the Linnaean binary nomenclature was a harmful invention because the generic names kept changing as the knowledge of the world's flora kept increasing, and the many binary names consisting of epithets in combination with different generic names would cause confusion. According to Oeder in this manuscript, it would be much better if, for each species, one were to refer to a specific illustration by citing a reference number that did not change. Holm argued against this by citing Linnaeus' Article 162 in Philosophia botanica (Linnaeus, 1751): 
Naturae opus semper est species et genus; that genera were easier to remember than species, and that the binary names with Linnaean genera were more practical than Oeder's ideas about numbers as fixed reference points for species. Oeder's views on species and genera are also made clear in the programme for the project (Appendix 1).

Although not specifically stated in Oeder's writing, we know that during his stay in Paris, he personally met a number of French scientists, particularly Georges-Louis Leclerc, Comte de Buffon, and that Albrecht von Haller had been Oeder's teacher at the University of Göttingen. Reflections of what a species was and how species could be classified in genera and taxa of higher rank were expressed by Buffon in several parts of his Histoire naturelle, générale et paticulière ..., published in 15 volumes between 1749 and 1767. Buffon's first comment appeared in a general discussion of artificial versus natural systems of classification in an introductory essay De la manière d'étudier \& de traiter l'Histoire Naturelle and was an attack on the essentialist species concept: "Nature progresses by unknown gradations and consequently does not submit to our absolute divisions when passing by imperceptible nuances, from one species to another and often from one genus to another. Inevitably there are a great number of equivocal species and in-between specimens that one does not know where to place and which throw our general systems into turmoil." (Buffon, 1749: 13; translated by Farber, 1972). Buffon elaborated on this idea in later works, including the fourth volume of Histoire naturelle, particularly in his discussion of the taxonomic differences between the horse and the donkey and the poodle and the greyhound, where he, like Oeder, accepted the existence of species by adopting a biological species concept (Mayr, 1982: 260-263): "It is then, in the characteristic diversity of species that the intervals between the nuances of nature are the most noticeable and best marked. One could even say that these intervals between species are the most uniform and the least variable of all, since one can always draw a line of separation between two species, that is, between two successions of individuals that cannot reproduce with each other. This distinction is the strongest that we have in natural history. All the other distinctions that one could choose for comparing individuals would not be as constant, as real, or as certain. These intervals [between species] will be, therefore, the only divisions to be found in our work. ... Each species - each succession of individuals that can successfully reproduce with each other - will be considered as a unit and treated separately. We will not use families, genera, orders, and classes, any more than nature does. A species, then, is only a constant succession of similar individuals that can reproduce together." (Buffon in Buffon \& Daubenton, 1753: 384-385; translated by Farber, 1972: 267).

Oeder's teacher, Albrecht von Haller, held similar views, but Haller, perhaps even more than Buffon, had a sense of an important aspect of taxonomy, which mostly escaped Linnaeus, the variability of species. Stafleu (1971: 247) expressed Haller's views like this: "One of the most important differences between Linnaeus and Haller lies in their attitude toward the fixity of species. For Linnaeus, this fixity was a dogma of no mean importance ... Haller was a biosystematist avantla-lettre." About Haller's views on the Linnaean generic reform and sexual system Stafleu (1971: 248) wrote: "The Linnaean generic reform was totally unacceptable to [Haller], and the sexual system, with its pragmatic aim, he rejected as superficial ..." 
Precisely these views are prominent in Oeder's statements in Appendix 1 and in his Monitum in the Icones (Appendix 5), where hierarchical classification above the rank of species are discussed and questioned. Stafleu (1971: 248) also reviewed Haller's attitude to Linnaean nomenclature: "Both Haller and Linnaeus attempted to give purely diagnostic phrase names to their species. Haller, however, did not recognise the importance of binary nomenclature for species; he considered the nomina trivialia to be imprecise and leading to the wrong associations or ideas, obviously misjudging entirely their importance as simple code-designations." The documents in Appendix 1 and 5 show how deeply influenced Oeder was by this thinking. The Linnaean binomial nomenclature and sexual system were based on the genus, which according to Buffon, Haller and Oeder were defined by speculatively essential characters. Like Haller and Buffon, Oeder did not think that the Linnaean classification was sufficiently founded in scientific observations, and they wanted to widen morphological characters with knowledge of reproduction and ecology.

However, it was another related point that made the conflict between Oeder and Linnaeus break out in direct confrontation. In the first fascicle of the Icones, published shortly after the announcement in Appendix 1, Oeder listed wherever necessary a synonymy on chronological order, mostly beginning with names from Caspar Bauhin's Pinax and finishing with the Linnaean binary names from Systema naturae (Fig. 1). This way of presenting plant names did not go unnoticed in Uppsala. In the second edition of the Species Plantarum (Linnaeus, 1762-1763), Linnaeus retaliated by citing Oeder's plates in the Icones with reference to the first name cited by Oeder, as if this was the name he accepted (Fig. 2). Oeder reacted in Dec. 1762 by writing a letter in Latin to Linnaeus. The letter is preserved in the correspondence of Linnaeus in the Linnaean Society of London (Oeder, 1762); it was transliterated by Schiødte (1871), but is in Appendix 2 translated into English for the first time. Linnaeus answered quickly and apparently sharply in a letter that is not preserved, but Oeder replied already at the beginning of January 1763 (Oeder, 1763; translated in Appendix 3), and his reply quotes nearly the entire letter he had received from Linnaeus. In it Oeder tried to refute Linnaeus point by point with the arguments we have already seen. Apart from this private correspondence, Oeder also distanced himself from Linnaeus' action in Species Plantarum, ed. 2, in a Monitum at the end of the text in fascicle 2 (1763) of the Icones (translated in Appendix 4). Here, he again declared that he did not accept any one name in preference to any other. He would prefer that authors, who might want to refer to plates in the Icones, did it by citing the plate numbers only.

\section{Oeder's difficulties with his ideas in practice, and his use of Linnaean nomenclature}

Although Oeder followed his ideas about nomenclature in all the fascicles he edited, ending his chronological list of synonyms with the trivial (binary) name of Linnaeus in the botanical part of his 10th edition of Systema Naturae (Linnaeus, 1758-1759) or in the second edition of his Species Plantarum (Linnaeus, 1762-1763), there are a few exceptions from that use of Linnaean trivial names. This seems to be because 


\section{Pament und Drte \\ Der in dicfem erfiten Softe

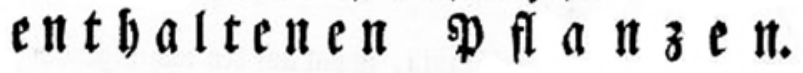

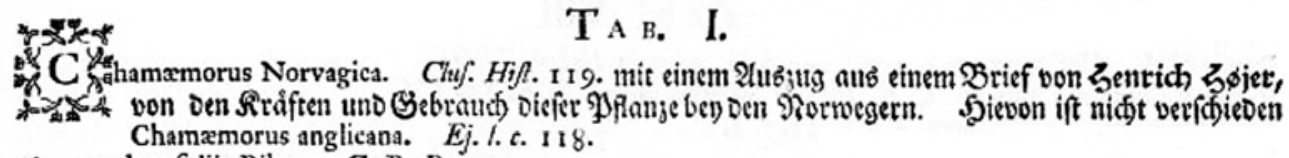
Chamarubus foliis Ribes. C. B. P. +80 .

Chamæmorus Norvagica. S. Paul. Fl. 339. n. 189. Barthol. med. dan. 106. Pontopp. H. N. N. I. 215. c. fig.

Chamamorus Raj. Syn. III. 260. Hiff. 654.

Rubus Chamamorus, foliis fimplicibus lobatis, caule unifloro. Linn. S. N. fl. lapp. 208. t. V. fl. fv. 449.

Lanbes ramen. In Porwegen Miultebar, fo auch bey den Dánen uno Deutịen.

Ort. Şdufig in gans $\mathfrak{R}$ orwegen auf und an Den Esebirgen, an fumpfigten torfartigen Stellen, Die im Sommer oben auf austrofnen.

\section{T A B. II.}

Pedicularis, lapponica, caule fimplici, foliis pinnatifidis ferratis, calycibus bifidis obtufis. Limn. S. N.f. lapp. 242. t. IV.f. s. fl. fvec. 1. 507. II. 534 .

Dre. Sier und Dar in Porwegen auf Den Esebirgen, jwiften Gruus und Stein.

$$
\text { T А в. III. }
$$

Campanula ferpyllifolia. C. B. P. 93. prodr. 35. F. B. II. 816. Scheuchi. It. 131. 4540

Nummularia Norvagica. Kylling. Att. Hafn. II. 34.6. obf. г $30 . f$. C.

Nummularia fylveitris repens flore albo. Pontopp. H. N. N. I. 193 .

Serpillifolıa. Buxb. AOF. Petrop. II. 346 .

Linna, auctore Gronovio. Linn. gen. 692. Hall. Helv. 608.

Linnaa borealis. Lim. S. N. f. lapp. 250, t. 12. f. 4 . f. fi. 562 . Kalm. It. II. 263.

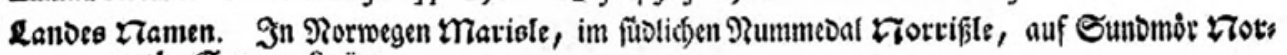
rettle Grees. Ström.

Ort. Durdfgebenos in Porwegen auf moofigten fdjattigten Girunde.

Fig. 1. The nomenclatural summaries for the first three plates in the first fascicle of the Icones ... Florae Danicae, published by Oeder in 1761 (German edition). For Rubus chamaemorus, the synonymy begins with names by pre-Linnaean authors like Clusius (Clus. Hist.), Gaspar Bauhin (C.B.P. [Pinax]), Simon Pauli (S. Paul. Fl.) and John Ray (Raj. Syn.). In the Linnaean names, the epithet of the nomen triviale is marked with italics.

Oeder did not add new Linnaean binary names in the Icones when he needed a name not published by Linnaeus: Plate 161 shows a grass which has only a phrase name: "Gramen parvum, paniculatum, alpinum, ... Scheuchz. agr. 140 t. IV", identified by Lange (1887) as a variety of Agrostis canina L. Plates 317 and 318 show two Arctic species of Gentiana: Plate 317: "Gentiana an [meaning 'related to'] bavarica", identified by Lange (1887) as Gentiana serrata Gunnerus, and Plate 318, provided with a phrase name: "Gentiana corolla 4-fida ", identified by Lange (1887) as Gentiana tenella Rottb. Plate 345 shows an orchid: "Serapias bulbis fibrosis", identified by Lange (1887) as Cephalanthera rubra Rich., and Plate 403 shows a species of Carex: "Carex spica androgyna", identified by Lange (1887) as C. alpina Sw. (C. vahlii Schkuhr), now C. norvegica Retz. 


\section{fteilaris. 10.'SAXIFRAGA foliis Serratis, caule nudo ramoTo, petalis scuminatis, \\ Sasifraga folijs lanceolatis dentato-ferratis, caule nudo timplici $\mathrm{Fl}$. fece $35 ;$; 367 . \\ Saxitraga caule nudo fimpici, foliis laneeolatis denta- tis, peta is acutis. Fl tipp. 175. \\ Sanicuia myofotis, floribus aioicantibus fere umbella- tis. Pluk. alm. 3, I. t. 58.f. 2. fु t. $222 . f: 4$. \\ Sedum mentanum hirfutum, mucronato \& dentato foito, tiore albo guttato, Mierif. hi/l. 3 p. $47^{8}$. $\int .12$. . 9.6 .13$. \\ Sedum aipinum IV. Oed. dan.t.23. \\ Hubut in Alpibus Spitsbergentibus, Lapponicis, Hel- veticis, Styriacis, Weftmorlandicis. \\ Flores ixferi.}

\section{TА в. XXIII.}

Sedulum alpinum quartum. Gefn. Schmied. Hift. fafc. I. n. $3^{6, t}$. VI.

Sedum montanum hirfutum, mucronato \& dentato folio, flore albo guttato. Morif. Hift. III. 478. S. 12. t. 9. f. I3.

Sanicula myoforis floribus albicantibus fere umbellatis. Plukn. t. 58. f. 2. ES. t. 222. f. 4 .

Saxifraga foliorum hirfutorum latiore apice dentaro, csule nudo fpicato. Hall. Helv, 400 .

Saxifraga, fiellaris, foliis ferraris, caule nudo ramofo, petalis acuminatis. Linn. $S . N$.

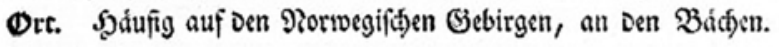

973. SAXIFRAGA foliis rhomboideis, acute ferratis, caule nudo, ramofo.

Sanicula montana minor CLUs. Pannon. p. 44I.

Santicula alpina aliquatenus adfinis I. B. III. p. 708 .

Sanicula monfotis . alpina, fioribus albicantibus, fere kmbellatis Pluknet. p. 33 1. t. 38. f. 2.

Icont OEDERI $t .23$.

\& tab 222.f. 4 .

Saxifraga foliis ferratis, cante mudo, ramofo, petalis acimninatis LINN. I. p. 572.

Ad rivulus alpinos ubique, nufquam in montanis.

Radix perennis, afpera, ramofa, plures producit foliorum cefpites. Ea craffula, ut Linnæus vocat cuneiformia . rhomboidea. primis lateribus integris, \& longioribus,

Fig. 2. Saxifraga stellaris provides an example of how Linnaeus and Haller cited the names in Oeder's Icones ... Florae Danicae. Above, the name Sedum alpinum IV Oed. dan. t. 23 is cited by Linnaeus as Oeder's accepted name (Linnaeus, 1762: 572-573); Linnaeus added a mistake by citing Gesner's Sedulum as Sedum. In the middle, Oeder's nomenclatural summary of the same species in Icones ... Florae Danicae. Below, the nomenclatural summary of the same species in Haller (1768: 418), who used the same style as Oeder, but only referred to Oeder's plate number, as Oeder himself had recommended.

However, in the little that has been written about the differences of opinion between Oeder and Linnaeus, it is generally overlooked that Oeder did use Linnaean binary nomenclature for species in his other works in the Flora Danica project. In his Nomenclator botanicus, Oeder (1769a, 1769b, 1769c) defined plant names in vernacular languages by relating them to Linnaean binomials. In the introduction, he stated, "At the same time I would like to advise you, for several reasons, always to incorporate 
the Linnaeus generico-trivial names, which, because of the general inventories of the natural kingdom to which they refer, and in which we find as definite notions of every matter [the meaning of the text is not entirely clear here], will be a comfortable tertium comparationis for the otherwise very fluctuating concepts of names of natural bodies in living languages." (my translation from Danish). The general impression from this lexicographic work is that Oeder in this work had realised the practical use of Linnaean binary names.

This is also the case with Oeder's last work in the Flora Danica project, the Enumeratio Plantarum (Oeder, 1770a), which only includes plants without flowers. For each species, the text is brief and in most cases comparable to a phrase name. Many of these phrase names were taken from Haller's Historia (Haller, 1768) or Dillenius (1741), while Oeder for almost all species of vascular cryptogams used Linnaean binary names. Again, the general impression of this work is that Oeder was aware of the practical use of Linnaean binary nomenclature.

\section{The nomenclatural summaries of the later editors of the Icones}

The first volume of J. E. Gunnerus' Flora Norvegica (Gunnerus, 1766) and O. F. Müller's Flora Fridrichsdalina (Müller, 1767) were the first botanical works on the Danish and Norwegian flora that consistently used Linnaean binary nomenclature and Linnaean nomenclatural summaries. Both Flora Norvegica and Flora Fridrichsdalina refer to all published plates of Oeder's Icones by plate-numbers, as Oeder had suggested. Nevertheless, as editor of the Icones, Müller strictly followed Oeder's principles of citing the oldest name first. At the end of fascicle 12, published in 1777, Müller commented on the citations of names, but he did not change Oeder's lay-out of the nomenclatural summaries: "With regard to the several editions of Linnaeus' System [a Naturae], the citation of volume and page have been omitted, these nomina trivialia can be found in publications by recent botanists. By the addition of the letter "L." the Knight's [Linnaeus'] version of the names can be distinguished from mine." (my translation from Danish). In 1777, Müller published an Index Iconum Florae Danicae as a separately paginated appendix to fascicle 12 . With 10 pages in folio, this index contains only Linnaean binomial names for the species illustrated in the first twelve fascicles.

The next editor, Martin Vahl, was an ardent Linnaean and all Vahl's other works, mainly on tropical plants, followed the Linnaean nomenclature strictly, for example his Symbolae Botanicae, vol. 1 (Vahl, 1790), where he revised selected species from the herbarium collected in Egypt and Yemen by P. Forsskål in 1762-1763. Nevertheless, as editor of the Icones, Vahl strictly followed Oeder's principles of citing the oldest name first.

Jens Wilken Hornemann followed Oeder's example in fascicle 22 and 23 (Fig. 3 ), while in fascicle 24, he changed to synonymies with an accepted Linnaean or later name first and introduced a significant number of new Linnaean binomial names, indicated with "(mihi)" (Fig. 4). In a few cases in fascicle 25, he returned to Oeder's 
style of nomenclatural summaries, but in fascicle 26 he consistently followed the Linnaean principles, while in a few cases in fascicle 27, he returned to Oeder's style. In fascicle 28, Hornemann consistently followed Linnaean principles, but there are not many synonyms in this fascicle because it contains many newly described taxa from Greenland. Finally, in fascicles 29 to 39, Hornemann followed the Linnaean principles, using a colon to distinguish between Linnaean binomials (or trinomial) and the Latin diagnosis of the accepted name.

Hornemann was aware of the conflict between Oeder and Linnaeus. When making a Nomenclator for the by then published fascicles of the Icones, he wrote a brief historical review of the work in Latin (Hornemann, 1827a): "Some have criticized Oeder for being somewhat unfair in his judgment of Linnaeus, and for having committed some errors in naming plants. The former is the result of a misunderstanding of Linnaeus' system, the latter is something that could very easily happen in a work of this amplitude. Besides, one should keep in mind that Oeder was a pupil of Haller's, and so he did not judge about the delimitation of genera and species in quite the same way as Linnaeus." (my translation from Latin). In a later review of the history of the Flora Danica project, Hornemann (1837) wrote: "Some has criticized Oeder for choosing to follow Haller's rather than Linnaeus' methods, but it is necessary to remember that in a work like Flora Danica the method is not significant, and that Oeder was of Haller's school, not Linnaeus', and that this did not have any other influence on Flora Danica than the fact that the synonymies were organised in a way different from how a disciple of Linnaeus would have arranged them." (my translation from Danish).

In his later years, Hornemann was poorly, and the young botanist Salomon Drejer (1813-42) collected plants for the Icones on his behalf. Drejer was only partly responsible for the preparation and initial editing of fascicle 40, which was published by his colleagues Joachim Frederic Schouw and Jens Vahl, who largely followed the principles of Hornemann's latest fascicles. F. M. Liebmann (1813-56) mostly presented the initial work of Drejer and Jens Vahl in the three fascicles he published - 41, 42 and 43. From fascicle 40, the accepted name was printed in bold; a practice also followed by the zoologist Japetus Steenstrup and Johan Lange in fascicle 44. Lange continued the editing of fascicle 45 to 50 with synonymies rather similar to those used by his contemporary botanists (Fig. 5) and concluded the editing of the last fascicle of the entire work, no. 51, in 1883, having in 1874 published a supplement with Norwegian and Swedish plants in three fascicles.

\section{Conclusion}

As demonstrated here, Oeder's ideas about taxonomy and nomenclature had longlasting influence on the way the Icones was edited. It is not clear why the subsequent editors, Müller, Vahl and initially also Hornemann, followed Oeder's ideas so closely. Although very specific about the practical aspects of the work with Flora Danica, the instructions from 1759 did not deal with the scientific aspects of the work, and changes to the instructions in the 19 th century were similarly practical. So why was 


\section{FLORAE DANICAE}

\section{$\mathrm{T}_{\mathrm{AB}}$. MCCLXVIII.}

Carypophyllus minimus muralis. Bash. pin. $2 \mathrm{I}$.

Gypfophila muralis, foliis linearibus planis, calycibus aphyllis, caule dichotomo, petalis crenatis. Amoen. acad. 3. p. 23. Lin. fp. pl. 533.

In Munimentis Cronborg \& prope Birkeröd Siælandize.

\section{TAB. MCCLXIX.}

Arenaria norvegica, caulibus fubteretibus procumbentibus: floribus binis terminalibus: foliis enerviis nudis. Gun. flor. Norv. P. II. No. 1 too. t. 9. f. 7·9.

Arenaria ciliata $\beta$. Wild. fp. pl. T. II. P. 1. p. 719.

In rupibus Wardöe \& in Monte Stegen Nordlandiæ.

\section{TAB. MCCLXX.}

Tithymalus pinea. Lob. icc. P. 1. 357.

Euphorbia Efista umbella multifida : bifida : involucellis fubcordatis, petalis fubbicornibus, ramis fteriliIn Holfatia. bus, foliis uniformibus. Anoen. acad. 3. p. 127. Lin. fpec. pl. P. 1. 660.

\section{TAв. MCCLXXI.}

Urtica aculeata, foliis ferratis. Bath. pin. 232.

Galeopfis Tetrahit internodies caulinis fuperne incraffatis, verticillis fummis fubcontiguis. $L i n$. fp. pl. P. 810.

Frequens inter fegetes Daniæ.

\section{TAB. MCCLXXII.}

Urtica iners tertia f. lamium fore luteo. Dod. pempl. 153.

Galeopfis Galeobdolon verticillis fexfloris irvolucro tetraphyllo. Lin. fp. pl. 810.

In nemorofis ad fepes raro.

Fig. 3. The nomenclatural summaries for the plates 1268-1272 in the 22 nd fascicle of the Icones ... Florae Danicae, published by Hornemann in 1806. In Hornemann's first two fascicles, his nomenclatural summaries followed the ideas of Oeder completely.

the nomenclatural torpidity so great, when the editors supported and used Linnaean nomenclature in their own works? One possible reason could be that the general scheme of the Icones, with its rigid formal structure of volumes, fascicles and format of tables, induced conservatism. The dramatic changes in the geographical area covered by the work, mainly because of Danish losses in the Napoleonic wars, duly influenced the otherwise very conservative title pages of each volume. The fact that the project from the outset was directly under the Danish crown, and was not associated with a University and without a permanent scientific committee to supervise the editors, may not have encouraged changes. Hornemann's work with repeated indexing and reviews of the entire project (Hornemann, 1809, 1827a, 1837) may have caused him to experiment with the nomenclatural summaries. From fascicle 30 (published in 1823), Hornemann read reports on the scientific interest of the new fascicles at the meetings of the Royal Danish Academy of Sciences and Letters (Hornemann, 1823, 1827b, 1829,1836 ; a report on fascicle 38 from 1839, shortly before he died, is only preserved 


\section{N O M E N C L A T U R A}

\section{ET \\ L OCI NATALES PLANTAR UM.}

\section{TAB. MCCCLXXXI.}

Eriophorum latifolism (Hoppe): culmis trigonis, foliis planiusculis apice triqvetris, pedunculis scabris Schrad. Fl. Germ. 1 p. 154. Erioph. polystachium Lin. In paluftribus et uliginosis vulgaris.

\section{TAв. MCCCLXXXII.}

Bromus afper ( in. fil.): panicula nutante, spiculis lineari-lanceolatis compresfis pubescentibus, flofeulis In fylvis Daniz raro. demum remotiufculis, ariftis rectis gluma brevioribus, foliis villofis fcabris. Schrad. l.c.p.360.

\section{TAB. MCCCLXXXIII.}

Bromns erectus (Smith): panicula erecta, spiculis lineari-lanceolatis compresfis, flosculis imbricatis, aristis rectis gluma breviorilus, foliis fasciculorum anguftisfimis ciliatis. Schrad, l. c. p. 357. Bromus pauciflorus Schumacher Enumerat, plantar. Sicell. P. 1. p. 32.

In agris circa Birkerod invenit celeberrimus Prof. Schtmacher et prope Dronninggaard amicisfimus Prof. Puerari, Botanices cultor indefeffus.

\section{TAB. MCCCLXXXIV.}

Potamogeton acuminatum: foliis ovato-lanceolatis planis in periolos definentibus, acuminibus subulatisa rigidis, fuperioribus oppositis, omnibus membranaceis, Schum. Emumer. pl. Sicell. 1. p. 49.

In lacubus Peblinge, Farum et Soröe frequens. An fpecie diverfum a P. lucenti?

\section{TAB. MCCCLXXXV.}

Primula fricta (mihi): foliis planis fubpetiolatis fubtus fubnudis, feapo elongato paucifloro, pedunculis crectis ftrictis, limbo tubo dimidio breviore.

Inveni hanc Primulam, a $\boldsymbol{P}$. farinofa cultura conftanter diverfam, in pratis et ad ripas amnium circa Tolgen et Röraas Norvegix.

\section{TAB. MCCCLXXXVI.}

Juncus campeftris (Lin.): var. spicis globofis densis, foliis nudis. An fpec. deftincta?

In turfofis alpinis circs Tronfieldet Norvegix inveni.

TAB. MCCCLXXXVII.

Epilobium mutans (mihi) : caule basi repente angulofo paucifloro, foliis alternis ellipticis denticulatis, pedunculis fub florefcentia nutantibus, ftigmate clavato.

In turfofis alpinis Norvegix.

Fig. 4. The nomenclatural summaries for the plates $1381-1387$ in the 24 nd fascicle of the Icones ... Florae Danicae, published by Hornemann in 1810 (Latin edition). From this fascicle, Hornemann's broke with Oeder's ideas of nomenclature.

as a manuscript). Therefore, at the Academy meetings, the most prominent Danish botanists and zoologists must surely have discussed the Flora Danica project, and in the report from 1829, Hornemann wrote that in the Icones he had introduced changes "in nomenclature due to the demand of the times and the changing views of the various editors." (my translation from Danish). The subsequent editors, all members of the Royal Danish Academy, followed Hornemann's tradition of giving a presentation in the Academy of new fascicles of the Icones. In spite of this, one cannot help thinking that editing the Icones was like steering a super-tanker: once the course had been set, it was not easily changed. 


\title{
NOMINA ET LOCI NATALES, ADJECTIS SYNONYMIS NONNULLIS BREVIQUE DESCRIPTIONE PLANTARUM IN HOC FASCICULO DEPICTARUM.
}

\author{
TAB. MMDCXLI.
}

Digitaria glabra $R . \& S$., multicaulis; foliis vaginisque glabris, ligula brevi; spieulis ovatis, plcrumque geminis, altera sessili, altera breviter pedicellata, in spicam unilateralem dispositis, spicis $2-4$ digitato-congestis; gluma superiore floreque sterili pubezcentibus; paleis thoris hermaphlroditi glabris, nitidis. - R.\&S. Syst. II, p. 471; Lange, Haandb. i den danske Flora ed. 2, p. 55; Panieum glabrun Gand. Agrost. helv. I, p. 22; (P. sanguinale Poll. palat. I, p. 57 ; F. D. 328 (pessime), noi L.); Digitaria humifusa Pers. Syn. I, 85 ; Hornem. Oec. Pl. p. 66.

In agris et ad vias, in Dania haud frequens et olim verosimiliter curo cerealibus introducta. Specimen delineatum ad Flensborg lectum.

Fig. a. Purs folli cum ligula. b. racbis intorescetitise eum pedicollis, floribus plesisque lesumtis. c. glumas. d. gluma suporior, aucta. c. alos sterilis. f. pales inferior, a dorso visa, eum stignatibus. g. pales superior, a ventre visa.

Liebmann et Joh. Lange direxerunt.

Obs. Species bec jam antea (Fl. dan. tab. 328, nomine Panici sanguinalis) depicta est, sed figura pessima et vix reeognoscenda.

\section{TАв. MNDCXLII.}

Avena hybrida Peterm., panicula squali, spiculis 2-3-1loriz, flore utroque aristato; glumis flores, aristâ exceptâ, superantibus; palea inferiore glabra v. basi pilis paucis vestita, apice membranaceo-bilida; raehi spicule fragili pilosa. - Peterm. in Rehb. fl. Saxon. p. 17; Koch Syn. ed. 2, p. 917; Lge. Haandb. ed. 2, p. 72; $\Lambda$. intermedia Lindgr. in Bot. not. 1841 p. $151 ; \mathrm{Fr}$. Herb. norm. VII, 89.

Inter segetes rarior: Specimina depicta legi al pagum Valby floræ hauniensis, ubi copioso provenit.

Fiy. 1. Planta florens. 2. Partieula rarais maturitatum versus erectis. a. spicula trifoza, glonis desurotis. b. xpieula billore. c. palea inferior. d. pstes superior. c. germon.

Fig. 5. The nomenclatural summaries for the plates $2641-2642$ in the 45 th fascicle of the Icones ... Florae Danicae, published by Lange in 1861 (Latin edition). Liebmann and Lange followed Schouw and the younger Vahl with regard to style of summaries, but stressed the accepted name with bold typography, which is very far from Oeder's ideas. Plate 2641 replaced Oeder's inadequate plate 328 from 1767.

In botanical taxonomy in general, part of the conflict between the views of Linnaeus and those of Oeder, Buffon and Haller was not resolved. A. P. de Candolle's Théorie élémentaire de la botanique (Candolle, 1813) breaks with many Linnaean ideas, but retains the binary nomenclature that Oeder rejected. Livre 1 and 2 of the Théorie élémentaire rejects the Linnaean sexual system in favour of a natural classification. Also Chapitre 2, De l'espèce et de ses variétés, in Livre 3, departs from Linnaean ideas and deals extensively with variation within and hybridisation between 
species, emphasising that the study of large numbers of herbarium specimens or the plants in nature is necessary to define the limitations of species. Yet, in that part of the Théorie élémentaire there is not a critical remark on Linnaean binary nomenclature for species, only a few comments on Linnaean views on variation and hybridisation. Even today, we have not completely developed the Linnaean nomenclature to reflect the natural variation in plants; unlike Oeder, the rebel, we have resigned ourselves with that part of the Linnaean tradition.

DEDICATION AND ACKNOWLEDGEMENTS. The author dedicates this paper on the taxonomy and nomenclature in the Flora Danica project (1761-1883) to David J. Mabberley on his 70th birthday in 2018. The contribution does not deal with David's main subjects in tropical Asian or Australian botany, but it is my hope that this paper will nevertheless fall within David's wide range of interests. Beginning in the 1980s, David has taken an interest in 18th and early 19th century botanists struggling with Linnaean classification and nomenclature (e.g. Mabberley, 1981, 1982, 2017a) and attempts at nomenclatural reforms (Mabberley, 1985b). Indeed, he has sometimes studied the works of one of the prominent figures in this paper, J.W. Hornemann (Mabberley, 1984). The Flora Danica project, as G.C. Oeder said in his general introduction, deals with "plants from a significant tract of land, from south of the River Elbe in the south to the Arctic Oceans in the north" (see Appendix 1). Therefore, it also connects with David's interest in the work of Robert Brown and Sir Joseph Banks, who were both involved in the natural history of Iceland and Greenland (Mabberley, 1985a: 137, 230-234, 330-331; Agnarsdóttir, 1994). David's interest in the art of botanical illustration (Mabberley, 2017b) is another link to a work with more than 3200 illustrations in colour, mainly drawn from nature. In addition, the memory of E. J. H. Corner, David's teacher at Cambridge, is honoured with this volume; besides his botanical achievements, Corner had in his youth a scholarly interest in Latin and, like G. C. Oeder, Corner frequently did not follow mainstream views.

The author wishes to thank Professor emeritus, dr. phil., fil. dr. h.c. Sten Ebbesen, University of Copenhagen, for invaluable help with the translation into English of the two Latin letters from Oeder to Linnaeus (Appendix 2 \& 3).

\section{References}

Agnarsdóttir, A. (1994). Sir Joseph Banks and the exploration of Iceland. In: Banks, R.E.R, Elliott, B., Hawkes, J.G., King-Hele, D. \& Lucas, G.L. (eds) Sir Joseph Banks. A Global Perspective, pp. 31-48. Kew: Royal Botanic Gardens, Kew.

Anonymous (2019). Royal Copenhagen Porcelain Manufactory. Two Flora Danica Custard Cups and Covers before 10 Mar 1863. https://www.rct.uk/collection/58013. Accessed 25 Apr. 2019.

Bencard, M. (2000). Det hvide guld. Porcelænets indførelse i Europa. In: Laursen, B.B. \& Nottelmann, S. (eds) Dansk Porcelcen 1775-2000, pp. 21-49. København: [Copenhagen]: Nyt Nordisk Forlag Arnold Busck.

Buchheim, G. (1979). A bibliographical account of Icones plantarum sponte nascentium in regnis Daniae et Norvegiae, better known as Flora Danica. Huntia 3(3): 161-178.

Buffon, G.L. (1749). Histoire naturelle, générale et particuliére, avec la description du Cabinet du Roi, Tome Premier. Paris: L'Imprimerie Royale. 
Buffon, G.L. \& Daubenton, J.-M.-L. (1753). Histoire naturelle, générale et particuliére, avec la description du Cabinet du Roi. Tome Quatriéme. Paris: L'Imprimerie Royale.

Candolle, A.P. de (1813). Théorie élémentaire de la botanique, ou exposition des principes de la classification naturelle et de l'art de décrire et d'étudier les végétaux. Paris: Déterville.

Christensen, C. (1924-1926a). Den danske Botaniks Historie, med tilhørende Bibliografi. I. Den danske Botaniks Historie fra de celdste Tider til 1912. 1. Halvbind (Indtil 1872). København: H. Hagerups Forlag.

Christensen, C. (1924-1926b). Den danske Botaniks Historie, med tilhørende Bibliografi. II. Bibliografi. København: H. Hagerups Forlag.

Dillenius, J.J. (1741). Historia muscorum, in qua circiter sexcentce species veteres et novce ad sua genera relatce describuntur et iconibus genuinis illustrantur cum appendice et indice synonymorum. Oxford: "e theatro sheldoniano".

Farber, P.L. (1972). Buffon and the concept of species. J. Hist. Biol.5(2): 259-284.

Friis, I. (1996). The Icones ... florae Danicae ... (1761-1883) as a source of names of flowering plants. Acta Universitatis Upsaliensis Symbolae Botanicae Upsaliensis 31(3): 7-25.

Gunnerus, J.E. (1766). Flora Norvegica, observationibus praefertim oeconomicis panosque norvegici locupletata, Pars prior, cum iconibus. Hafniæ [Copenhagen]: Pelt, et Nidrosiae [Trondheim]: Vinding.

Haller, A. von (1768). Historia stirpium indigenarum helvetiae inchoata, Tomus primus. Plantae flore composito, didynamiae, papilionaceae, cruciatae, meiostemones, isostemones, diplostemones. Bern: Societatis typographicae.

Hornemann, J.W. (1796). Forsøg til en dansk oekonomisk Plantelcere. Et Priisskrivt. Kjøbenhavn [Copenhagen]: C.L. Buch.

Hornemann, J.W. (1809). Historisk-kritiske Bemærkninger om Flora Danica. Skandinavisk Litteraturselskabs Skrifter 1809: 308-354.

Hornemann, J.W. (1823). [First communication in] Den physiske Classe. Oversigt over Videnskabernes Selskabs Forhandlinger 1822-1823: 3-5.

Hornemann, J.W. (1827a). Nomenclatura florae danicae emendata, cum indice systematico et alphabetico. Hafniae [Copenhagen]: H.F Popp.

Hornemann, J.W. (1827b). [Third communication in] Den physiske Classes Arbeider. Oversigt over Videnskabernes Selskabs Forhandlinger 1826-1827: 3.

Hornemann, J.W. (1829). [Second communication in] Physisk Classe. Oversigt over Videnskabernes Selskabs Forhandlinger 1828-1829: 4-5.

Hornemann, J.W. (1836). [First communication in] Den physiske Classe. Oversigt over Videnskabernes Selskabs Forhandlinger 1835-1836: 5-7.

Hornemann, J.W. (1837). Om Flora Danica. Naturhistorisk Tidsskrift, udgivet af Henrik Kröyer 1: 105-137, 417-475.

Jussieu, A.L. (1789). Genera plantarum secundum ordines naturales disp sita, juxta methoclum in horto regio parisiensi exaratum. Parisiis [Paris]: apud Viduam Herissant ... et Theophilum Barrois ...

Knudsen, H. (2014). Fortcellingen om Flora Danica. København [Copenhagen]: Lindhardt og Ringhof.

Knudsen, H. (2016). The story behind Flora Danica. Copenhagen: Lindhardt og Ringhof.

Lack, H.W. (2018). Die Einführung der binären Nomenklatur für Pflanzen im Ostseeraum. In: von Engelhardt, D., Kästner, I., Kiefer, J. \& Reich, K. (eds) Der Ostseeraum aus wissenschafts- und kulturhistorischer Sicht. Europäische Wissenschaftsbeziehungen 15, pp. 137-160. Achen: Shaker Verlag. 
Lange, J. (1887). Nomenclator "Florae Danicae", sive index systematicus et alphabeticus operis, quod "Icones Florae Danicae" inscribitur. Hauniae: Lehman \& Stage.

Linnaeus, C. (1751). Philosophia botanica. Stockholmiae: Godofr Kiesewetter. See also Linnaeus, C. (2003). Linnaeus' Philosophia botanica. Translated by Stephen Freer. Oxford: Oxford University Press.

Linnaeus, C. (1757). D.A. Prodromus florae danicae, quern, suffrag. experient. Facult. medic. in Regia Academia Upsaliensi, praeside, ... Carolo Linnaeo, ... pro summis in arte apollinea honoribus, more majorum legitime obtinendis, publicae censurae sistit Georgius Tycho Holm, Fyonia-Danus. In Auditorio carol. maj. d. ii. Jun. anni mdcclvii. Upsaliae [Uppsala]: L. M. Höjer, Reg. Acad. Typogr.

Linnaeus, C. (1758-1759). Systema naturae per regna tria naturae, secundum classes, ordines, genera, species, cum characteribus, differentiis, synonymis, locis. Editio decima, reformata, Tomus I [Regnum animale]; Tomus II [Regnum vegetabile]. [Tomus III, Regnum mineralia, was never published]. Holmiae [Stockholm]: Laurentius Salvius.

Linnaeus, C. (1760). Caroli Linnaei ... Amoenitates academicae seu dissertationes variae physicae, medicae botanicae antehac seorsim editae nunc collectae et auctae cum tabulis aeneis ..., vol. 5. Holmiae [Stockholm]: (Sumtu \& literis direct. Laurentii Salvii).

Linnaeus, C. (1762-1763). Species Plantarum exhibentes plantas rite cognitas, ad genera relatas, cum differentiis specificis, nominibus trivialibus, synonymis selectis, locis natalibus, secundum systema sexuale digestas. Editio secunda, aucta. Tomus I [1762], II [1763]. Holmiae [Stockholm]: Laurentius Salvius.

Mabberley, D.J. (1981). Edward Nathaniel Bancroft's obscure botanical publications and his father's plant names. Taxon 30(1): 7-17.

Mabberley, D.J. (1982). William Roxburgh's 'Botanical Description of a New Species of Swietenia (Mahogany)' and other overlooked binomials in 36 vascular plant families. Taxon 31(1): 65-73.

Mabberley, D. (1984). Pallas's Buckthorn and two and a half centuries of neglected binomials. Taxon 33(3): 433-444.

Mabberley, D.J.(1985a). Jupiter Botanicus. Robert Brown of the British Museum. Braunschweig: J. Cramer and London: British Museum (Natural History).

Mabberley, D.J. (1985b). William Theobald (1829-1908): unwitting reformer of botanical nomenclature? Taxon 34(1): 152-156.

Mabberley, D.J. (2017a). A note on the tonka bean and William Forsyth junior's 'A botanical nomenclator' (1794). Blumea 62: 87-89.

Mabberley, D.J. (2017b). Painting by numbers: the life and art of Ferdinand Bauer. Sydney: University of New South Wales Press.

Mayr, E. (1982). The growth of biological thought. Diversity, evolution and inheritance. Cambridge, Massachusetts and London, England: The Belknap Press of Harvard University Press.

Müller, O.F. (1767). Flora fridrichsdalina, sive methodica descriptio plantarum in agro Fridrichsdalensi simulque per regnum Daniae crescentium (1767). Argentorati [Strasbourg]: Johan Godofer Bauer.

Nottelmann, S. (1990). Flora Danica og den Kongelige Porcelænsfabrik / Flora Danica and the Royal Danish Copenhagen Porcelain Manufactury. In: Villumsen-Krog, O. (ed.) Flora Danica og det danske hof / Flora Danica and the Royal Danish Court, pp. 174193. København [Copenhagen]: Det kongelige sølvkammer, Christiansbog Slot / The 
Royal Silver Room, Christiansbog Castle.

Nottelmann, S. (1994). Flora Danica and the Royal Copenhagen porcelain manufactory. In: Andersen, F. \& Nesbitt, P. (eds) Flora Danica, pp. 51-61. [Catalogue of an Exhibition organised by Finn Andersen of the Danish Cultural Institute, Edinburgh, and curated by Paul Nesbitt of the Royal Botanic Garden Edinburgh]. Edinburgh: Royal Botanic Garden Edinburgh and Danish Cultural Institute.

Oeder, G.C. (1761a). Efterretning om et Verk, som på Kongelig Befaling skal udgives, FLORA DANICA kaldet, tilligemed en Prøve-plade af Multeboers Planten (Rubus Chamaemorus). [Copenhagen]: no publisher indicated.

Oeder, G.C. (1761b). Programma de Opere FLORA DANICA dicto, jussu regio edendo, adjecta speciminis loco icone plantae, Rubus Chamaemorus. / Prospectus d'un Ouvrage intitule: FLORA DANICA, avec unue Planche qui represente, le Rubus Chamaemorus. Copenhague [Copenhagen]: C. \& A Philibert.

Oeder, G.C. (1761c). Nachricht von der ausgabe eines Werkes, FLORA DANICA genannt, mit einer Probe-Platte von der Pflanze Rubus Chamaemorus. [Copenhagen]: no publisher indicated.

Oeder, G.C. (1762). Letter to Carolus Linnaeus dated 8 December, 1762 NS. The Linnaean correspondence. linnaeus.c18.net/Letter/L3179.

Oeder, G.C. (1763). Letter to Carolus Linnaeus dated 5 January, 1763 NS. The Linnaean correspondence. linnaeus.c18.net/Letter/L3204.

Oeder, G.C. (1764a). Flora Danica. Volumen primum. Elementa botanicae. Pars prior. [Copenhagen:] Fratrum Philibert et viduam Frantz Christ. Mumme.

Oeder, G.C. (1764b). Flora Danica. Erster Band. Einleitung zu der Kräuterkenntnisz. Erster Theil. Kopenhagen: Frantz Christian Mummes Wittwe und Nicolaus Möller.

Oeder, G.C. (1764c). Flora Danica. Første Bind. Indledning til Plante-Læren. Første Part. Kjøbenhavn [Copenhagen]: Nicolaus Møller.

Oeder, G.C. (1766a). Flora Danica. Volumen primum. Elementa botanicae. Pars posterior. Hafniae [Copenhagen]: Fratrum Philibert et viduam Frantz Christ. Mumme.

Oeder, G.C. (1766b). Flora Danica. Erster Band. Einleitung zu der Kräuterkenntnisz. Zweyter Theil. Kopenhagen [Copenhagen]: Frantz Christian Mummes Wittwe und Nicolaus Möller.

Oeder, G.C. (1766c). Flora Danica. Første Bind. Indledning til Plante-Læren. Anden Part. Kjøbenhavn [Copenhagen]: Nicolaus Møller.

Oeder, G.C. (1769a). Nomenclator botanicus inserviens Florae Danicae, continens plantarum in terris danicis sponte nascentium nomina vernacula in linguis gallica, anglica, germanica, suecica, danica, cum nomenclatore synonymico-linnaeano, \& pharmaceutico-linnaeano. Hafniae [Copenhagen]: Fratrum Philibert et viduam Frantz Christ. Mumme.

Oeder, G.C. (1769b). Nomenclator botanicus zum Gebrauch bey der Flora Danica. Kopenhagen [Copenhagen]: Fratrum Philibert et viduam Frantz Christ. Mumme.

Oeder, G.C. (1769c). Nomenclator botanicus til at bruge ved Flora Danica. Kjøbenhavn [Copenhagen]: Fratrum Philibert et viduam Frantz Christ. Mumme.

Oeder, G.C. (1770a). Enumeratio plantarum Florae Danicae, id est sponte nascentium in Regnis Daniae et Norvegiae; ducatibus Slesvici et Holsatiae; Comitatibus Oldenburgi et Delmenhorstiae. Part prima: Cryptantherae. Hafniae [Copenhagen]: Sumptibus Heineck \& Faber. Typis Cl. Philibert. 
Oeder, G.C. (1770b). Flora Danica oder Verzeichnis der in den Königreichen Dänemark und Norwegen, in den Herzogthümern Schleszwig und Holstein, und in Graffschaften Oldenburg und Delmenhorst wildwachsenden Kräuter. Kopenhagen [Copenhagen]: Nicolaus Møller.

Oeder, G.C., Müller, O. F., Vahl, M., Hornemann, J.W., Liebman, F.M. \& Lange, J. (17611883). Icones plantarum sponte nascentium in regnis Daniae et Norvegiae, in ducatibus Slesvici et Holsaticae, et in comitatibus Oldenburgi et Delmenhorstiae; ad illustrandum opus de iisdem plantis, regio jussu exarandum, Florae danicae nomine inscriptum. [Varying title pages in Latin, German and Danish]. Vols 1-17. Hafniae [Havniae, Hauniae: Copenhagen]: [Varying publishers, mainly] Fratres Philibert \& vidua Mumme, Philibert, Heinicke \& Faber. See also Table 1.

Schiødte, J.C. (1871). Af Linnés Brevveksling. Aktstykker til Naturstudiets Historie i Danmark. Naturhistorisk Tidsskrift 3. Række, 7: 333-522.

Stafleu, F.A. (1971). Linnaeus and the Linnaeans. The spreading of their ideas in systematic botany, 1735-1789. Regnum Vegetabile 79: i-xvi, 1-386.

Vahl, M. (1790). Symbolae Botanicae, sive plantarum, tam earum, quas in itinere, inprimis orientali, collegit Petrus Forskål, quam aliarum, recentius detectarum, exactiores descriptions necnon observationes circa quasdam plantas dudum cognitas. Pars prima. Hauniae [Copenhagen]: Nicolaus Møller et filius.

Wagner, P. (1990a). Det kongelige værk Flora Danica / The Royal Work Flora Danica. In: Villumsen-Krog, O. (ed.) Flora Danica og det danske hof / Flora Danica and the Royal Danish Court, pp. 14-41. Copenhagen: Det kongelige sølvkammer, Christiansbog Slot / The Royal Silver Room, Christiansbog Castle.

Wagner, P. (1990b). Icones Floraer Danicae. Flora Danicas "Urteteignere" og "Illuminationsskolen for Quindekiønnet" In: V. Woldbye (ed.) Blomster fra Sans og Samling, pp. 93-100. København [Copenhagen], Kunstindustrimuseet / Rhodos. [An English abstract on pp. 104-105 is headed "The Illustrators of Flora Danica"].

Wagner, P. (1994). The Royal Work Flora Danica. In: Andersen, F. \& Nesbitt, P. (eds) Flora Danica, pp. 13-28. [Catalogue of an Exhibition organised by Finn Andersen of the Danish Cultural Institute, Edinburgh, and curated by Paul Nesbitt of the Royal Botanic Garden Edinburgh]. Edinburgh: Royal Botanic Garden Edinburgh and Danish Cultural Institute. 
Appendix 1. Oeder's invitation to subscribe to a new work called Flora Danica (1761)

Below is my synthesis and translation (mainly from the Danish text; Oeder, 1761a) of Oeder's presentation and invitation to subscribe to a new work called Flora Danica. The Latin and French texts (Oeder, 1761b) and the German text (Oeder, 1761c) were published at the same time with slightly different layouts. The Danish and German texts are very similar and slightly more detailed than the texts in Latin and French, and the German version contains a list of the plant species illustrated in the first 60 plates of the work, using only the Linnaean binary names for the species. In the Danish version, Linnaean binary names are called "generiske-triviale Navne" [generic-trivial names]. This means that the names include a generic name plus a "trivial" name (a specific epithet), in agreement with Philosophia botanica (Linnaeus, 1751: Article 257). In the German version, the same names are called "Genericotrivial Namen", and they were used for the sake of brevity.

\section{Note about a work, called FLORA DANICA, which is going to be published at Royal Order, together with a plate showing the cloudberry plant (Rubus chamaemorus).}

A significant element in the Royal Botanic Institute, recently established in Copenhagen, is the publication of a work that will account for all the plants that grow wild and without the help of humans in the two kingdoms of His Majesty and in his other lands in Europe. The complete title of the work will be organised according to [the names of] the two kingdoms and the other lands, but here we will refer to it with the shortened title of FLORA DANICA.

His majesty's main intention with this work is to benefit his people, and he aims to spread knowledge in his countries about the native plants. It is necessary to spread this botanical knowledge among the inhabitants of the country, because botany cannot be of general use as long as it is only a science for a few botanical scholars. In order to achieve the benefit that the public can reasonably expect from knowledge of a realm of nature from which humans harvest their greatest benefits, but about which, when we need to speak frankly, our knowledge is still far from achieved in full, but from which we have yet much to expect, and our knowledge about which must not be restricted within too narrow limits, as, for example, to medicine alone, then it first of all depends on whether both the knowledge of the plants and the opportunity to make further experiences with them are compiled [in an accessible form].

These opportunities [to make further experiences with plants] are generally present for those who work with plants, when these plants are to be utilised for humans in their various occupations in daily life, but in particular for those people who live in the countryside, as it were, live at the bosom of nature, and who emphasise the practising of agriculture. In this numerous class of useful citizens of this state [the kingdoms of Denmark, Norway, etc.] there are not many who are scholars by profession, but, on the contrary, there are many who, when studies of classical and foreign languages are excepted, have all the qualifications needed by a lover of learning: insight, education, prosperity, time, desire, and to which must be added, a particular interest in botany rather than other sciences that their household and private circumstances may bring with them. Therefore, to help such friends of botany, this science must be explained in the languages of the country, which is Danish and German, and beyond this, I do not find that anything else but resolve is required. The science must as far as possible, and without harm to its profoundness, be presented in an easily intelligible way, and I am of the opinion that botanists, if they really want to, could make many parts of their subject really much more easily comprehensible to those interested [than they have done until now]. Furthermore, the means [scientific works] that are made available to such interested people must also be sufficient in themselves, so that no other foreign books are absolutely necessary.

It is in agreement with these ideas that the principles according to which our FLORA DANICA will be organised and written, and in addition His Majesty, in order to realise his paternal intentions, will, as a Royal gift, distribute a large number of copies of the work to the clergy of his kingdoms and lands in such a way that the copies will be given to the bishops or superintendents of each diocese and can be lent for some time to those clergymen who would benefit the most from the work, and in turn assist the Royal Botanical Institute and Garden [in Copenhagen] with their correspondence.

In addition to this main intention, it is the will of the King, who loves and supports all sciences, that also foreigners should be able to benefit from the work, which undoubtedly will be possible because it 
contains plants from a significant tract of land, from south of the River Elbe in the south to the Arctic Ocean in the north, from the 53rd to 70th degree of northern latitude, and it contains plants of the mountains and of the sea-shores, as well as plants from many other types of land, and the work can thus be useful in large parts of Europe, especially the northern parts. FLORA DANICA must therefore also be published with a Latin text, and the inhabitants of these countries can choose between Latin and their native language. Before I report in detail on the organisation of this work, I must first mention some general considerations on an enterprise of this kind, especially about the collection of engravings, which is the most expensive part of the work.

A project of this kind cannot be realised by a private person. Its execution requires greater costs, more sustained support and more time than what can be expected from the powers of a private person or what can be anticipated in one person's lifetime, with all its fragility and vagaries of fortune, and the history of botany shows us more than one example of the frail nature of this type of projects. However, FLORA DANICA is not a private project, its publication is an integrated key element in the constitution of the Royal Botanic Institute [in Copenhagen], and the preparation, continuation and improvement of this work is an official duty for any professor employed at the Royal Botanical Garden. Therefore, purchasers of this work should not fear that it will cease to appear and thereby increase the number of so many other works of this kind that have remained incomplete. Without boasting, I can assure that this Flora will remain unsurpassed as long as no other government will endeavour a similar project.

It is true that one can sufficiently identify plants with the help of words and descriptions alone, and that drawings of the plants are not absolutely necessary, but, on the other hand, that oral or written scientific guidance by botanists is required in order to fully understand even the best drawings. Nor is it my opinion that because a botanist with reference to a drawing of a plant can teach others to recognise it, he can ignore words to describe it, just as if no drawing of it existed. Once I have declared this, I do not expect even the strictest botanist would say that I overestimate the value and usefulness of drawings. His own experiences will tell him how easy his work, especially with regard to the comparison of texts by various botanical authors, will be for all the plants that are represented by good drawings, and I am sure that this opinion will be shared by those who are not professional botanists. It is incontestable that one can identify plants with much more ease and faster when, in addition to descriptions in the literature, one has the use of engraved illustrations than when one has to identify the plants with descriptions in words alone. If, since the invention of the art of printing text and engravings jointly, one had had provided more good drawings instead of incomplete descriptions, then botanists would have been saved much of the sour work necessary to identify and apply synonyms, and there would have been less reason to complain about the amount of redundant names; then the essential knowledge of plants would have become more widespread than now, and one would have progressed more with knowledge about the uses of plants than is presently the case.

All objections to the use of engravings, or to increase the number of botanical works with such engravings, state that such works are expensive. To these objections, one can answer with another question: what is most expensive, the time and trouble that such a work saves the botanist, or the money that he has spent to acquire this aid in his work? Anyone can respond to this question in agreement with one's own wishes, but reason requires that as much aid as possible is offered as he [who needs it] can afford. Secondly, it is not really the natural price of good engraved illustrations in itself that makes it difficult for a lover of botany in just moderate economic circumstances to buy them, but the fact that he cannot acquire a homogeneous and complete collection of illustrations [relevant to the area he is interested in], but, when he just wants drawings of the plants that can grow in his area on a square mile, have to acquire a whole collection of prints where he finds drawings of very varying quality and nature, often with the same plants again and again, infinitely many times, and what he really wants to use is being dispersed among a lot of unnecessary matter.

It is this circumstance that complicates the work of the lover of botany and the science itself. That such a difficulty is remedied remains a good but vain desire as long as the world's rulers do not support this useful science. If a sovereign in southern Europe wanted to request the production of a work like FLORA DANICA to cover his own country's plants, then firstly his own country would reap the fruit of this, namely the benefit that we promise ourselves from FLORA DANICA in these northern kingdoms, and secondly, botanists in all countries would have two works, which together would contain the vast majority of Europe's plants. These two works would enable them with the groundwork for their further 
work, so that they could add what was found in their area. The gaps in the works could perhaps then be so much faster remedied by a third or fourth sovereign in eastern, western or middle Europe. In this way, a complete and orderly collection of drawings of all European plants would be produced without repetition. Thus a common ground for all botanical science would be provided, and botany would be infinitely easier and science promoted.

Now I will describe the planned layout of FLORA DANICA. It is the will of His Majesty that with the work it should both be possible to identify the native plants, and that their usefulness to the inhabitants of these kingdoms and countries should be explained. The entire work therefore falls into two main parts, one part of the botany (Botanica pura), and another part that treats the use of the botany for human benefit (Botanica applicata). In this message I only talk about Botanica pura. The preparation of the part that will treat the benefits of the plans is transferred to a society, of which I am a member and will have to be the writer. About that part, a separate announcement will be published in due course.

The text of FLORA DANICA will be published separately from the drawings. Many reasons necessitate this arrangement of the work. The engravings must be divided into fascicles, and in this part of the publication the circumstances do not allow one to issue them according to order, similarity or system. On the other hand, a systematic consistency must be found in a book that explains a science in which the systematic order is the soul. An appropriate format must be chosen for the two parts of the text that deal respectively with the general introduction to the botany and the enumeration of the plants, so that one can carry the book along when looking for the plants in nature. Finally, one needs to think about the needs of different users, as not everyone can expect to acquire all the parts of the work, and yet one would desire that the work would be able to help them all.

Buyers of the work may please to consider the collection of engravings as a so-called Herbarium vivum, which one may collect and increase when there is an opportunity for it, and which one may organise in an appropriate order when a sufficient number of engravings has been collected. One can store this entire Herbarium as a convenient tool to be compared with the writings of botanists and in order to illustrate these writings.

The plates will only be provided with the words FLORA DANICA and a number. The first fascicle will contain 60 engravings, and the second fascicle will begin with the Tab. 61 . The size of the printing plates will be adjusted to the size of the plants, but all plates are printed on the same size of paper, the size of which can be seen by the specimen plate. On each plate, only one plant is reproduced, except for small plants belonging to the Dillenian moss class; the publication of these will therefore come last so that the drawings of them can be gathered and several of these plants put on the same plate according to their similarity. The large plants are illustrated according to their habitus in a certain diminished size, and characteristic parts will be shown close to [the large illustrations] and represented in full size. For the small plants, a magnifying glass will be used, not only to show what the naked eye does not see, but also to give the artist an opportunity with the brush to express clearly what a good unarmed eye should be able to see. If the drawing of the entire plant does not give the necessary characteristics, the plates throughout the work will show all parts of the plants that indicate species differences. All plants are drawn after nature and after fresh plants, and I hope that connoisseurs will be delighted with the work that will be performed by the artists employed at the Botanical Institute. They are father and son, Michael and Martin Rösler; the first is an engraver, the second is a draughtsman. With each fascicle of engravings, there will be printed sheets with the names of the plants illustrated in the fascicle.

The release of these fascicles will begin before the release of the text; their release will continue while the text is being published and will persist after the text has been printed, until all the plants belonging to FLORA DANICA have been drawn. Each owner of this collection thus has free hands to both bind the fascicles as they appear, but also, if they so wish, to leave them unbound until the publication of the collection has progressed so far that they can put the plates in systematic order.

This collection of prints will contain drawings of both common and rare plants. Our intention is to serve the inhabitants of these kingdoms and lands, which will require such a plan. All plants deserve attention, and when the work is to serve its purpose, it must be sufficient in itself and other works should not be absolutely necessary. For the reasons stated above, and because of the needs of the botanical science, I hope that foreign buyers and professional botanists will be satisfied with a collection of homogenous drawings that also include the most common plants. 
The text's parts are as follows:

1. A general introduction to the botany as well as a separate educational dissertation.

2. An enumeration of the plants found in the countries of His Majesty; according to the rules for distinctive marks of each species, these marks are listed as many as necessary and not more than just needed to allow the species to be distinguished from each other. This is because this enumeration is intended to be used as a handbook.

3. A collection of comprehensive and detailed characteristics or descriptions of these plants.

These three parts are supposed to be a whole, but they are so designed that each part becomes a book for itself, which will be complete so that one does not necessarily need the other. These parts of the text will be sold both collectively and separately, both with and without the fascicles with plates, whereby any user can, after economic circumstances, be served.

The first fascicle will be published by Easter, 1762, and will illustrate 60 species on 60 engravings, which for brevity will be indicated by Linnaeus's generic-trivial names, and thus one fascicle will be published every year. Over time, one will try to make the fascicles bigger, as most buyers would most likely wish to complete the collection. The [experience with the] completion of the first fascicles will further determine this.

The first part of the text will be delivered to the domestic buyers [in Denmark, Norway, Schleswig, Holstein, etc.] by the end of 1762; the foreign buyers will get it together with the second fascicle.

The enumeration and descriptions of the species will be done as soon as I have either completed or almost completed my journeys in Denmark and His Majesty's German provinces; and since my trip through Norway has ended, the other required trips for Flora Danica will not take very long.

No prepayment is required, only a subscription, so that it can be determined what number of copies needs to be printed. In particular, buyers who want hand coloured engravings must indicate this in sufficient time, as only the copies ordered will be coloured. Subscribers will receive proof of their subscription, and the subscription price for an uncoloured copy of the first fascicle is 4 Danish Riksbankdaler and 9 Riksbankdaler for a coloured copy, but those who do not subscribe will have to pay a quarter more, and it will not be possible to order coloured copies after the end of the subscription period. The payment must be made cash upon delivery, and the subscription will be organised here in Copenhagen with me and at the bookshops of Mr. Philbert and Mr. Ackerman. Elsewhere, buyers need to address the one who has conveyed this message.

Copenhagen, 1 May 1761, Dr. Georg Christian Oeder, Royal Professor of Botany.

Appendix 2. First letters from Oeder to Linnaeus after the publication of the second edition of Species Plantarum, dated 8 Dec. 1762

Schiødte (1871) published a transcription of the original Latin text of this and the following letter. There are a few errors in Schiødte's transcriptions, corrected here by Prof. S. Ebbesen in his translation. The letters are also available on-line transcribed and in facsimile as Oeder $(1762,1763)$.

To the illustrious Carl Linnaeus, golden knight, chief physician to the King etc.

Many greetings from Georg Christian Oeder.

Having seen the first volume of the new edition of your book entitled Species Plantarum, which only came into my hands these days, I am induced to once again earnestly ask you to do what I asked for in my last letter: not to refer to the Pictures in Flora Danica except by the number of each plate, leaving out the names.

I have explained in the Prospectus of the forthcoming work the reason and causes why we publish the pictures of the plants separately from the descriptions or prose or text, as they say, [sermone et textu, ut dicunt - Oeder wants to say 'text', but using textus in this sense was considered unclassical, so he first gives the classical sermo, which however does not convey precisely what he means, then adds textus, but with an excuse for using an un-classical turn of phrase ('as they say')] and it should be clear to anyone 
who looks at the sheets of pictures appended to the first fascicle that the goal has only been to provide (while the text is being prepared) a preliminary list of the synonyms used by the most important authors who by way of description or selection of characteristics or by means of a picture have contributed to the knowledge about each plant, in order that the buyers should not receive completely unknown plants. I just provide synonyms, and do not proclaim any one of them publicly in my name or want it to become established - that is not my job, and if ever it will be so, then certainly not in this connection. I order those synonyms chronologically, starting with the finder [a translation of inventor; Oeder means the first botanist who recognised the species and named it] and ending with your quite recent Pinax [a comparison of Bauhin's Pinax with Linnaeus' recent Species Plantarum and botanical part of Systema Naturae], omitting anyone in-between who has not contributed anything of importance to the investigation of the plant with the exception of G. Bauhin, who collected the synonyms up to his own time; and I cannot make myself believe that it matters at all whether one follows a forwards or a backwards order, or that anything can be concluded about my feelings one way or the other toward the authors I refer to, as though I prefer the ones that I name first or fail to respect you as the master of this science [arte - in accordance with classical Latin Oeder does not use scientia, but ars for botany as a discipline] because I cite your Systema at the end, given that it is the most recent book.

In these circumstances I would have wished — in fact, I would have expected — you to cite this first fascicle with the numbers written on the plates, and, as I have in all cases recorded your names with the trivial ones inserted in them, that you would then, after mentioning your own books, add my Flora, as I see you have done in the case of Cornus suecica.

Instead, most illustrious man, you have decided to generally cite the first name among the synonyms relating to each table, as if it was the name adopted by me. However far this is from my intentions, it would have been tolerable if only you had also named the books of the authors from whom those synonyms are drawn. [The words "the books of the authors from whom" is a translation of auctorum libros unde. Oeder may also have meant "the books (with indication of authors) from which"]. But now, when readers of your book, e.g., in the last line under Saxifraga stellaris (and similarly in several other places in which I am mentioned) see "Sedum alpinum, IV [often erroneously transcribed as '13']] Oed. Dan. t. 23", what on earth will those readers think of me as long as they have not seen my book and do not know me? And what of you, by your leave, when they get access to my book? In the first case they will believe [credent - Schiødte (1871) wrongly has crederent] that I am a fool, unless, perhaps, someone out of kindness, finding it improbable that such a man can have been charged with publishing a work in the name of the King [the letter has opus regio nomini edendum, an error for opus regio nomine edendum. Schiødte (1871) wrongly has dedendum for edendum], or someone accustomed to reading Clusius' books suspects that there is some typographical error. In the second case they will be amazed at your amazing way of citing my words and my intentions. For sure, illustrious man, if you are willing to evaluate the whole matter calmly, you will find it to be such that if someone out of animosity towards me were to wish to covertly suppress me and my work, this is how he might plan it.

Yet, I trust that your integrity of mind is not inferior to your scientific knowledge, and that you are so removed from such a scheme that you rather share my sorrow that an occasion has arisen for such a suspicion.

Till now you have hardly had a chance, illustrious man, to get to know me for better or for worse, except what Forskål, as you yourself wrote, reported to you about me, and although I have not become famous, I am not conscious of harbouring in me anything unworthy of myself or of the job of which I have been put in charge, where everything has to be arranged starting from nothing and where one has to pause between the first steps.

Much as I value you and your friendship, if I manage to merit it, I do not wish ever to seek anyone's, no matter how famous a man's, favour in any other way than one that is worthy of both.

So, trusting your integrity and fairness, illustrious man, I hope that you are willing to prevent that the wrong that I, even against your will, must fear due to your citations continues, and to correct the wrong already inflicted.

As soon as a convenient occasion offers itself, I shall send you a complete copy of the first fascicle, painted by our best workmen, and then I ask you to give back the half part that you now have in your hands to the splendid young man Fabritius who will deliver this letter to you. The second fascicle is sweating under the press. In the meantime, until it comes out complete, I shall, if you so wish, send you as 
loose leaves as many of the tables as have been printed, clean though, i.e., without colours.

The latest letter from Forskål was written in Cairo and forwarded in June this year from Livorno ["in June this year" apparently belongs with "delivered", but it seems possible that Oeder meant it to belong with "written"], from where I am every day awaiting the seeds and manuscripts that he mentions, if only the merchants do not lack diligence. In the letter was contained a specimen of a plant that he intended to mark with my name, but that plant is certainly a species of Cleome, and more precisely violacea. If you so wish, I shall send it to you.

Farewell, and trust that I am among those who consider it no mean commendation to have obtained the esteem of leading men in this science.

Copenhagen, 8 Dec. 1762.

Appendix 3. Reply from Oeder to Linnaeus' arguments against the nomenclature in the Icones, dated 3 Jan. 1763

To the illustrious Linnaeus many greetings from Oeder.

I am not at all in a rage, but I care for truth and my reputation, two things that a good man ought to hold dearer than anything else, and so I owe both truth and myself a response to your recent letter of 24 Dec. 1762. To keep it short and at the same time clear, I have decided the best would be to copy a part of your letter and present my comments below.

I shall not add a word more except for mentioning the esteem in which I hold you, illustrious man, for your tremendous merits towards botany, in spite your obvious unfriendliness towards me.

Farewell.

Copenhagen, 3 Jan. 1763.

Here is the excerpt from your letter:

Since you are in a rage, as I can see, you may not admit reasons, but if you admitted them, you would not be angry with me but rather with yourself, if I may speak in the manner of a friend. [Oeder's punctuation here joins "If I may speak in a friendly way" with the following period.] The main points [in the words of Linnaeus in the lost letter from Linnaeus to Oeder, but with the points numbered by Oeder] are these:

By your intercession etc.

The most high and mighty King of Denmark with his most generous hand sent 1) you to the provinces of his realm to investigate the native plants. An excellent draughtsman made extraordinarily beautiful drawings of the plants. You added synonyms according to a chronological sequel, although none 2) of them pleased you. I do not understand, 3) nor, perhaps, does anyone else, how you can release a Royal work 4) without descriptions done on the spot, and in particular without 5) names assigned to the plants, - something I have never seen done by anyone except by Meriana in her Surinamensia; but then she was a woman.

I could not 6) mention you and cite your Flora without a name. There were no names, except for the synonymic ones. Consequently, I had everywhere to cite the first name of the paragraph, 7) in order to indicate the table containing a drawing of the plant; not, however, in order to indicate the name, as you did not offer any of your own.

Who ever mentioned the 8) last synonym in the work of an author [as the accepted name]? If I had done that, what could not you yourself have judged about my egocentricity? [philautia, literally "love of self" - the on-line transcription (see at alvin-portal.org) wrongly has philantia both here and in Oeder's comments.] And what could not 9) everybody else have judged?

But you urge 10) that I ought to have named the author from whom you took the first of your names. I have many times mentioned 11) Vaillant, Barrelier etc. when they had taken over a name from 
Tournefort (without naming Tournefort, however) because I wished to direct the reader to a beautiful observation or picture. [The word 'picture' is a translation of figura - everywhere else it is a translation of icon.] For I have not cited older authors for the sake of their erroneous names but for the sake of their illustrations; if I had mentioned the original author, the reader would believe that I directed him to an observation, and would have found himself mislead.

G. Bauhin also put forward the synonyms in chronological order, but always placed his own name before them. 13) If you had done the same, you would not feel sorry because of me or of others. You are accusing yourself of an error, not other good people. In case you wish to take my advice, 14) you should together with the next fascicle publish a catalogue of your names, so that the readers can know which name to use as yours. This is what this science itself will require of you, this is what befits you as editor of such a splendid and truly royal work. You can also add your descriptions, to prevent 16) malevolent people from giving a negative interpretation of your work, saying that the draughtsman has performed his job excellently, while you have done nothing. Etc. Linnaeus]:

Here are my comments [Oeder's comments to the points he had numbered in the letter from

1) Allow me, as a unique defence of myself, and let no one take offence, allow me to tell you a fact that you seem not to know: for what it is worth, the whole Botanical Institute in Copenhagen [the Royal Botanical Garden and Library, separate from the botanical garden belonging to the University of Copenhagen] was started and is being continued according to my plans. I have selected the draughtsman whom you praise, he draws under my directions. Please do not be too ready to despise this man [hunc hominem - Oeder means himself] whom other important men must know better than you can.

2) They neither please me nor displease me. For the synonyms are taken where they are found, and are not cited for the sake of the name (which contributes nothing to the knowledge of the thing and merely calls to the mind the idea of a thing already known), but in order to more clearly identify [clarius declarandi - literally 'more clearly clarify'] the place in the book to be cited.

3) Why not? Cannot one publish a collection of pictures without descriptions as well as descriptions without pictures, the way geographical tables [are published] without geographical descriptions and geographical descriptions without geographical tables? [Oeder's "geographical tables" are obviously maps; the ad verbum translation has been kept here because Oeder sees maps as geography's counterpart of botany's illustrations of plants.]

4) In fact, I have promised the descriptions, and they will be published within not too many years, which I (and I am not alone) hope that you will survive. The reasons for separating the descriptions from the pictures have been made clear in the prospectus. Please read it before criticising.

5) Well, the pictures are now for the first time published as copies or forms of the things in lieu of a herbarium, and Meriana, for all her being a woman, was right as long as she simply concentrated on establishing the forms of things. For if she had added names, what more could they contribute to getting hold of the things [adquisitionem rerum - Schiødte (1871) has adcognitionem, but the original letter adquitionem. By a lapsus pennae Oeder has dropped the si after adqui...], being isolated and outside the interconnections of a system? We, for our part, have added the synonyms in order that the buyers of this herbarium that we are currently providing them with should be able to compare it with the writings of botanists.

6) You could not? If only you had everywhere cited my Flora the way it is done under Veronica 13 and Cornus 4, or the way you in Systema Naturae cite Miller's, Du Hamel's and Plumier's pictures.

7) Then you ought to have cited the number engraved on the plate itself, and placed it before the paragraph corresponding to each of them.

8) When authors are cited, one does not cite the synonyms collected by them, but their own names or names that they have explicitly adopted as their own, wherever they have decided to transmit or explicitly adopt such names.

9) Not at all. If next to your names, you had indicated that the plant defined by you is represented by a picture, identified by its number, in Flora Danica, who would ever have been able to accuse you of egocentricity?

10) And rightly so. For you cannot have failed to notice that the way you mention me without [mentioning] the books from which the names are taken that you cite as mine, those names are rendered ridiculous, and this solely by your fault.

11) Vaillant and Barrelier and the rest issued from the school of Tournefort adhered to the 
nomenclature familiar to them, i.e. Tournefort's. I have not professed anything of the kind.

12) I do not cite these more remote authors because of the elegance of their names, but for the sake of the praise that is due to the finders and first describers [descriptoribus - Schiødte (1871) wrongly has descriptionibus], in particular the brilliant Clusius. So much the less you ought to impute to and foist on me those names, which make no sense in our or in any time without the simultaneous mention of their authors.

13) Bauhin's professed purpose was to compose a list or concordance of names. My purpose has for the present solely been to indicate [indicandi - Schiødte (1871) wrongly has vindicandi] to the buyers the most important books with which they could compare the pictures of this herbarium [icones sive herbarium hocce: 'the pictures or this herbarium'. Oeder also in several other places indicated that Flora Danica might be considered a sort of herbarium.]

14) If my entreaties can obtain anything from you, I earnestly ask you not to cite our pictures except by mention of the numbers written on the tables.

15) How, I must ask, do you show that? Is it really necessary that every new author add to the heap of names that is already too big a burden for botany? Will you forbid me to venerate you and other masters in this science unless I permanently select one and swear fealty to him? Or is the knowledge about some plant based on its name rather than on the characteristics by which each species is to be distinguished from all other citizens of the vegetable kingdom? If someone decides to arrange in a proper order these characteristics, whether discovered, selected and defined by himself or by others, with a view to a given number of plants, e.g., those native to a certain province, in order that when looking at live plants his readers may be guided to the characteristic, i.e. the complex and sum of the marks pertaining to each plant, that fits whichever plant is under consideration - if he decides under each characteristic, separated from its neighbours, [taking it] as the true foundation of all things that may be predicated of some plant, to cite the authors who have written about such a plant, indicating either just the page and place in the book or also subjoining the name that each author has assigned to the plant, while he himself adds no name that he himself has made up, nor explicitly identifies any from the heap of synonyms to be the one he prefers and considers the principal one and his own - will you then convict such a man of inexperience of the science and the light of today's letters, [and] admonish him as a barbarian, indeed, ignorant of the books and what goes on in the world of letters?

16) They are certainly malevolent and have forgotten what I promised in the prospectus; or, if they are aware of the plan of the work, they are even more unfair and arrogant, since they spurn what has not yet seen the light of day. Far be it from me to count you among such men, but you might conveniently have refrained from even mentioning such a suspicion that does not offend me more than my superiors. 
Appendix 4. Oeder's admonition in fascicle 2 of the Icones (1763), translated from the German version of the text.

I find it necessary here again briefly to repeat the reasons given in the information about the publication of this work why this collection of illustrations is published separated from the text. There are lovers of herbal knowledge who would find it inconvenient to acquire this collection of engravings, so if one wanted to serve them, then the promised parts of the work that are to contain a presentation of herbal knowledge in words, could not be placed in an unbreakable connection with this collection of engravings. It was also necessary to supply this collection of illustrations bit by bit, because if they were to have printed all at once, they would have had to burden the buyers, as well as the publisher, with an all too great expenditure at once, and also this work had to be begun as soon as possible, if we were to see the end of it in our own days. Besides, we could not cut the text into as many portions as the fascicles of illustrations appear in, because in the science of herbs, more than in any other science, almost everything depends on a good method, and without the guide of the system even the experienced herbalist cannot find his way through the plant kingdom, and the beginner cannot enter it at all.

So I have asked all buyers and sellers of this collection of illustrations, and I ask you repeatedly that you accept and consider it as a so-called herbarium or collection of dried plants, or as a collection of topographic maps, which may serve to explain any description of the earth, and in your judgements do not forget that in issuing these fascicles with engravings, and each time I organise a new one, I have no intention other than this: to supplying faithful and clear illustrations of our native plants. Now, these illustrations keep their peculiarities and will always have the same value and use, whatever botanical system one wants to assume, and by the way, even if I did not want to add a printed line, then the illustrations could, as long as this happened, be associated to each table [of systems of the plant kingdom] by their numbers, therefore they could always be used equally well by all botanists, with simple reference to the number on each table. If I had also indicated either a name newly coined by myself, on the plate itself, or in the sheets which follow with each fascicle [the nomenclatural summaries], for which name most pleasing to me would have been specified, what would the illustration win thereby? Or what would that help with regard to your information, because the memory and the knowledge of the things do not rest on the names, but the names, with all remaining scientific knowledge and new information, are based on illustrations and descriptions? Now, for my sake, everyone may call a plant as he pleases, either with one of those previously known names that are familiar to him or, in cases where he likes it, with a new name, if only there is something to which these names can be attached, an unchangeable monument to the plants. If we only want to reflect on how little we can hope that the tyrannical language-use of our many botanical names for the plants and daily new ones, from which one, although not without inconvenience, may help oneself as long as one has the writings of the botanists at hand, may become penetrable. It is a vain demand that we can tell the truth, even with equity, as long as we cannot do the impossible, and what will remain impossible, to determine unchangeably the limits of similarities among creatures, that is, define the larger and smaller collections of species, which we accept according to their different levels, classes, orders, and genera, or genus superius and inferius, with the necessary reliability, so that we are not always forced with irresistible reasons to recognise and accept the same genera.

The authors are cited on the sheets of text that follow with each fascicle of illustration only with the intention that our illustrations may be compared with the writings of other botanists, and I hereby declare publicly that I do not prefer any of the names, which I usually cite in chronological order. I also repeat the request that the gentlemen who do me the honour of citing the Flora Danica in their writings, merely should do so by mentioning the number engraved on each plate, but in particular I have to mention the Lord Knight Linnaeus, whom I admire and hold in a high regard, and whom I do not wish to be disturbed by anything. I implore that he does not, as he has begun in the new edition of his book Species Plantarum, continue to refer to the Flora Danica in such a way that he cites the name which is in the first line of the synonymy of each plate, even omitting to mention the book from which it is taken, and attributes it to me as the name chosen by me, whereby such readers, who have his book alone, really cannot know what they should think of me. And if the Lord Knight means that, by virtue of his rule in Philosophia Botanica, § 319 ["In the case of synonyms, the best name should be at the head of the column; such a name should be either one used by another botanist and chosen, or one peculiar to the author." (Linnaeus, 1751: Article 319)], has to proceed like that, then he cannot hold it against me that I oppose such a rule relating to a rather arbitrary matter, which is the way of writing [synonyms]. This I do with the natural right according to which every author is entitled to declare his own opinion.

\section{G.C. Oeder}


